\title{
A DIVERSE ASSEMBLAGE OF LATE EOCENE WOODS FROM OREGON, WESTERN USA
}

\author{
ELISABETH A. WHEELER ${ }^{1,2, *}$, STEVEN R. MANCHESTER ${ }^{3}$ \\ 1 North Carolina State University, Box 8005, Raleigh, NC, 27695-8005, USA; e-mail: elisabeth_wheeler@ncsu.edu. \\ ${ }^{2}$ N.C. Museum of Natural Sciences, 11 West Jones St., Raleigh, NC, 27601, USA. \\ ${ }^{3}$ Florida Museum of Natural History, University of Florida, Dickinson Hall, 1659 Museum Road, Gainesville, Florida, 32611-7800, USA; \\ e-mail: steven@flmnh.ufl.edu. \\ *corresponding author
}

Wheeler, E. A., Manchester, S. R. (2021): A diverse assemblage of Late Eocene woods from Oregon, western USA. - Fossil Imprint, 77(2): 299-329, Praha. ISSN 2533-4050 (print), ISSN 2533-4069 (on-line).

\begin{abstract}
Well-preserved silicified woods from a site near the town of Post, Oregon, western USA, provide insights into the late Eocene vegetation and climate ca. 36 million years and data for comparing with both older and younger wood floras regionally and globally. The composition of this wood flora, taken into consideration along with taxa identified from silicified fruits and seeds of the same locality, provides a more complete picture of the former vegetation. We recognize woods belonging to the families Anacardiaceae (Pistacia terrazasae sp. nov.), Cannabaceae (Celtis popsii sp. nov.), Cercidiphyllaceae (Cercidiphyllum cf. alalongum R.A.ScotT et E.A.WheELER), Fagaceae (Fagus dodgeii sp. nov., Lithocarpoxylon ashwillii sp. nov., Lithocarpoxylon sp., Quercus sp.), Hamamelidaceae (Hamamelidoxylon crystalliferum sp. nov., H. cf. suzukii E.A.WHEELer et T.A.Dillhoff), Juglandaceae (Pterocaryoxylon sp.), Malvaceae (Wataria kvacekii n. sp.), Platanaceae (Platanoxylon cf. haydenii (Felix) Süss et Müll.-Stoll, Platanus sp.), Sapindaceae (Acer, 2 spp.), Trochodendraceae (Trochodendron beckii (Hergert et H.K.Phinney) R.A.Scott et E.A.Wheeler). This assemblage, which we refer to as the Post Hammer flora (UF 279), is comparable in age to the nearby Teater Road flora known mainly from fossil leaf impressions. Comparing the functional traits of the Hammer woods to the older Clarno Nut Beds woods attests to changing climate in the region, including an increase in seasonality.
\end{abstract}

Key words: John Day Formation, fossil wood, Anacardiaceae, Cannabaceae, Cercidiphyllaceae, Fagaceae, Hamamelidaceae, Juglandaceae, Malvaceae, Platanaceae, Sapindaceae, Trochodendraceae

Received: September 14, 2021 | Accepted: November 30, 2021 | Issued: February 18, 2022

\section{Introduction}

Central Oregon in the west-coastal United States is home to a sequence of middle Eocene to Early Oligocene terrestrial sediments that contain abundant and diverse fossil woods, leaves, fruits and seeds, and vertebrates (Chaney 1948, Hanson 1996, Retallack et al. 2000, Dillhoff et al. 2009). The middle Eocene Clarno Nut Beds deposit includes a rich fossil fruit and seed assemblage (Scott 1954, Manchester 1994) as well as the world's single most diverse assemblage of fossil woods (Wheeler and Manchester 2002). The fossil woods described herein are ca. 8 million years younger from a late Eocene deposit of the John Day Formation near the community of Post, Oregon. These were investigated as part of an ongoing treatment of the flora at the Post Hammer locality (UF locality 279), which includes at least ten fruit types (Manchester and McIntosh 2007). Twelve woods were introduced previously, representing the families Aceraceae, Anacardiaceae, Cercidiphyllaceae,
Fagaceae, Hamamelidaceae, Juglandaceae, Malvaceae, Ulmaceae, and Cupressaceae (Wheeler et al. 2006). Woods referable to Trochodendron beckii, Cercidiphyllum alalongum, and Liriodendroxylon multiporosum were described earlier (Scott and Wheeler 1982; see Wheeler and Manchester 2002 for locality clarification) and a more detailed treatment of the ulmaceous woods from the same flora was presented by Wheeler and Manchester (2007). Three assemblages from sites east of Post are currently under study: Brummers Spring (UF 254), Dietz (UF 278), and Hammer (UF 279).

In this article we focus on woods of the Post Hammer site and discuss their significance for understanding past floristic diversity, providing data for biogeographic and phylogenetic studies, and providing insights into woody plants' responses to changing climates. We describe the woods in alphabetical sequence by family and compare the incidence of features considered of ecological significance to the older Nut Beds wood assemblage. 


\section{Materials and methods}

\section{Locality}

The Post Hammer locality (UF 279) is situated about three $\mathrm{km}$ east of the town of Post, Oregon, and is named informally for Michael Hammer, a devoted fossil collector who brought it to our attention. The silicified woods are found loose in eroded tuffs that are situated in the upper part of the Clarno Formation near the transition to the John Day Formation. A minimum age for these wood sites is provided by a white tuff overlying the fossiliferous tuff at UF locality 278. Sanidine crystals from this white tuff give an ${ }^{40} \mathrm{Ar} /{ }^{39} \mathrm{Ar}$ date of 36.21 \pm 0.26 MA ( $n=26$; Manchester and McIntosh 2007). There are no datable tuffs in or immediately below the fossiliferous horizon to provide a maximum age. However, this late Eocene date may be a reasonable approximation of the age of the Post woods, contrasting with the middle Eocene age of the Clarno Nut Beds.

\section{Sample preparation}

The University of Florida (UF) collections at the Florida Museum of Natural History include more than 80 specimens of silicified wood from the Hammer locality. After examining them with a handlens and/or dissecting microscope, we selected examples of what appeared to be different wood types for thin sectioning. This paper describes 16 wood types. Eight additional angiosperms represented by secondary xylem, a palm, and one conifer from the same collection remain undescribed.

A diamond lapidary saw was used to cut thick sections (wafers) of transverse (TS), tangential (TLS), and radial (RLS) surfaces. One side of the wafer was smoothed to remove saw marks, and then affixed to a glass side using 24hour transparent epoxy. The sections were then ground until they were thin enough (ca. $30 \mu \mathrm{m})$ to allow seeing anatomical details with transmitted light microscopy. Initial grinding was done using a Buehler petrographic thin section grinding machine. Final thinning was done by hand, using a glass plate and a slurry of carborundum grit. Cover slips were mounted using Canada Balsam to improve clarity for light microscopy. Samples are deposited in the palaeobotanical collections of the Florida Museum of Natural History, University of Florida, Gainesville; in this paper individual samples are referred to by their UF specimen numbers.

\footnotetext{
Affinities

Possible relationships of the fossils to modern woods were determined by searching the InsideWood database (InsideWood 2004-onwards), using some of the strategies described by Wheeler (2011) and Wheeler et al. (2020). The search criteria used are given, i.e., IAWA hardwood list feature numbers (IAWA Committee 1989) followed by the codes " $p$ " for present, " $r$ " for required present; "a" for absent, "e" for required absent. Subsequently, descriptions and slides of the suggested matches were compared to the fossil. Samples of extant woods are referred to by their wood collection numbers, most abbreviations as given by Index Xylariorum 4.1 (Lynch and Gasson 2010).

The text-figures illustrating the features used to establish relationships show $\mathrm{TS}=$ transverse section, $\mathrm{RLS}=$ radial
}

longitudinal section, and TLS = tangential longitudinal section.

For quantitative features, we mostly report average (standard deviation), range; if three values are given, this is minimum - average - maximum.

The minimum diameters of the samples were estimated from the growth ring curvature and/or divergence of the rays. Although our fragmentary samples do not allow for providing information on dbh (diameter breast height, a common forestry measurement), we consider this crude estimate to be useful for indicating whether the sample came from juvenile or mature wood. There can be differences between juvenile and mature wood anatomy, especially in quantitative features and ray structure (e.g., Carlquist 2001). Most of the descriptions in InsideWood are for mature wood samples, so this needs to be kept in mind when making comparisons.

We refer to images of modern wood samples by Index Xylariorum 4.1 numbers (Lynch and Gasson 2010).

\section{Nomenclature}

There is a tradition among some Indian and European palaeobotanists that fossil woods should be assigned to a genus ending in-oxylon or-inium, even when the fossil wood has a combination of characters unique to an extant genus, e.g., Cistoxylon for a wood with features unique to Cistus (Gottwald 1992), Evodinium for woods thought to resemble Evodia (Bande and Prakash 1984). The International Code of Botanical Nomenclature does not require or recommend that fossil wood names have these endings. In our monograph on woods from the middle Eocene Nut Beds flora, our approach to naming was: "When a fossil wood has a suite of anatomical features characteristic of an extant genus, we assign it to that genus. Collinson (1986) provided rationale for this approach. This does not preclude the possibility that the wood may have belonged to a plant that had leaves and/ or reproductive structures different from the specified extant genus" (Wheeler and Manchester 2002: 11). We continue this approach here as well because we think that doing so provides information on mosaic evolution and variation in how different plant parts change through time.

New names of fossil plants and other nomenclatural acts are registered in the Plant Fossil Names Registry, which is hosted and operated by the National Museum, Prague for the International Organisation of Palaeobotany, each with a unique PFN number.

\section{Systematic palaeobotany}

Family Anacardiaceae R.BR., 1818 nom. cons. Genus Pistacia L., 1753

\section{Pistacia terrazasae sp. nov.}

Text-fig. $1 \mathrm{a}-\mathrm{i}$

Holotype. Designated here. UF 279-24545 (Textfig. 1b-i).

Paratype. Designated here. UF 279-85025 (Text-fig. 1a).

Plant Fossil Names Registry Number. PFN002712 (for new species). 


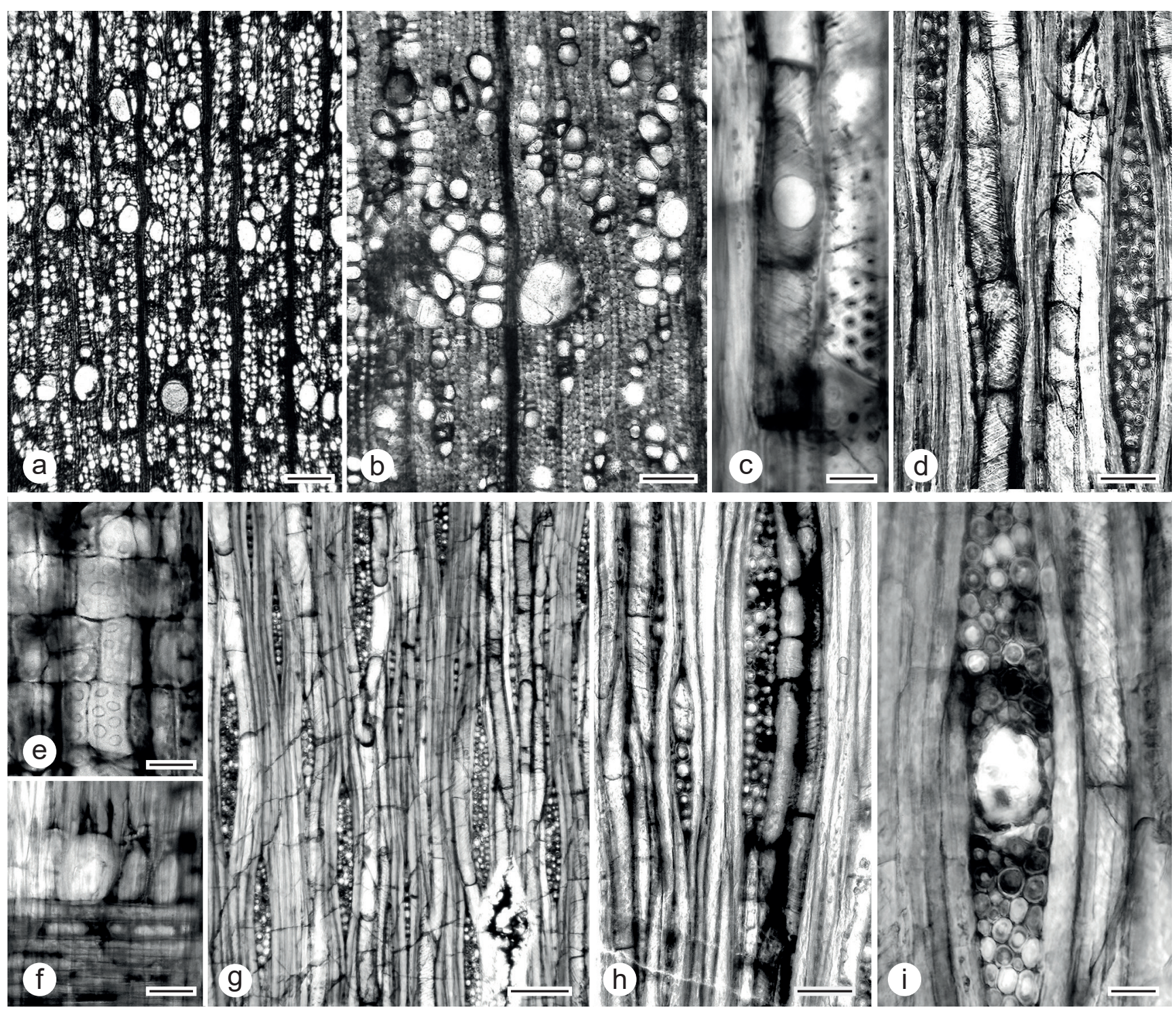

Text-fig. 1. Pistacia terrazasae sp. nov., a: UF 279-85025; b-i: UF 279-24545. a: Ring-porous wood with widely spaced solitary earlywood vessels; latewood vessels in radial multiples of 4 or more and in clusters, TS. b: Growth ring boundary, fiber walls thin to thick, TS. c: Simple perforation plates, alternate intervessel pits, helical thickenings in vessels, TLS. d: Multiseriate rays to 4-seriate, tyloses in vessels, helical thickenings throughout body of vessel element, and alternate intervessel pitting, TLS. e: Vessel-ray parenchyma pitting with reduced borders, oval in outline, RLS. f: Marginal row of upright cells, one inflated and crystalliferous, procumbent body cells, RLS. g: Multiseriate rays mostly 3-seriate, occasionally 4-seriate, uniseriate rays usually $<\mathbf{1 0}$ cells tall, TLS. h: Ray with enlarged crystalliferous marginal cell, to left of C, TLS. i: Ray with canal, TLS. Scale bars: $200 \mu \mathrm{m}$ in $\mathrm{a}, \mathrm{g} ; 100 \mu \mathrm{m}$ in $\mathrm{b}, \mathrm{d}, \mathrm{h} ; 50 \mu \mathrm{m}$ in $\mathrm{c}, \mathrm{i} ; 20 \mu \mathrm{m}$ in $\mathrm{e}, \mathrm{f}$.

Table 1. Comparison of Pistacioxylon (arranged by age, oldest to youngest) and Pistacia terrazasae. EW VTD = earlywood vessel tangential diameter in $\mu \mathrm{m}$; $\mathrm{EW}$ row $=$ number of rows of wide earlywood vessels; IVP $=$ horizontal diameter of intervessel pits in $\mu \mathrm{m}$; Cry = crystals, $\mathbf{A b}=$ absent, $\mathrm{UpR}$ - in upright ray parenchyma cells, Tyl = in tyloses; $\mathbf{R W}=$ width in cell number of rays without canals; $\mathrm{C}=$ common, $\mathrm{U}=$ Uncommon; $\mathrm{Eo}=$ Eocene, $\mathrm{OI}=$ Oligocene, $\mathrm{Mio}=$ Miocene, $\mathrm{I}=$ late, $\mathrm{e}=$ early.

\begin{tabular}{|l|c|c|c|c|c|c|c|}
\hline \multicolumn{1}{|c|}{ Taxon (Reference) } & EW VTD & EW row & IVP & Cry & RW & Canals & Age, Location \\
\hline Pistacioxylon muticoides (1) & $75-188$ & 1 & $6-8$ & $\mathrm{Ab}$ & $1-3(-4)$ & $\mathrm{C}, 1-3$ per ray & Ol, France \\
\hline P. hollieisii (2) & $117(105-165)$ & $4-5$ & $7-10$ & $\mathrm{Tyl}$ & $1-3$ & $\mathrm{U}, 1$ per ray & $1 \mathrm{Mio}, \mathrm{Germany}$ \\
\hline P. leiloensis (3) & $170(109-265)$ & 1 & $5-8$ & $\mathrm{Ab}$ & $1-5^{*}$ & $\mathrm{U}, 1$ per ray & $1 \mathrm{Mio}$, China \\
\hline P. praeterebinthus (4) & $80-105$ & $2-3$ & $6-8$ & $?$ & $1-5^{*}$ & 1 per ray & Mio?, Germany \\
\hline P. sp. (4) & $120-150$ & $2-3$ & $7-19$ & $?$ & $1-5^{*}$ & $1-2$ per ray & Mio?, Germany \\
\hline P. ufuki (5) & $81(42-130)$ & 1 & $5-7$ & $\mathrm{Ab}$ & $1-3$ & $\mathrm{C}, 1-3$ per ray & e Mio, Turkey \\
\hline Pistacia terrazasae sp. nov. (this paper) & $89(57-139)$ & 1 & $7-9$ & $\mathrm{UpR}$ & $1-3(-4)$ & $\mathrm{U}, 1$ per ray & 1 Eo, USA \\
\hline
\end{tabular}

1. Dupéron (1973), 2. Selmeier (2000a), 3. Cheng et al. (2012), 4. Gottwald (2004), 5. Akkemik et al. (2018)

* Ray width described as to 5 cells wide, however, it seems probable that is the width of rays with canals. 
Repository. Paleobotany Collections, Florida Museum of Natural History, Gainesville, Florida, USA.

Etymology. Named for Teresa Terrazas to acknowledge her comprehensive treatment of the wood anatomy of the Anacardiaceae

Type locality. UF 279. About $3 \mathrm{~km}$ east of Post, Crook County, Oregon, USA.

Type stratum and age. John Day Formation, Eocene.

Diagnosis. Growth rings distinct. Wood ringporous with a narrow earlywood zone, mostly 1 pore deep, earlywood vessels not contiguous; latewood vessels predominantly in radial multiples, some in clusters. Helical thickenings present. Perforation plates exclusively simple. Intervessel pitting alternate. Vessel-ray parenchyma pits with reduced borders, rounded to oval in outline. Fibers non-septate. Axial parenchyma not common, scanty paratracheal. Radial canals present. Rays heterocellular with a few marginal rows of square to upright cells. Crystals in marginal ray parenchyma cells

Description. Growth rings present, marked by radially flattened latewood fibers, and differences in vessel diameter and density between latewood and earlywood of subsequent rings. Ring-porous.

Earlywood vessels solitary and rounded to slightly oval in outline, earlywood pore zone $1(-2)$ pores deep, not contiguous; latewood vessels mostly in radial multiples and clusters, solitary latewood vessels angular in outline (Textfig. 1a, b); average tangential diameter of earlywood vessels 89 (22) $\mu \mathrm{m}$, range 57-139 $\mu \mathrm{m}$; perforations exclusively simple (Text-fig. 1c); intervessel pits alternate (not angular in outline) (Text-fig. 1c, d), 7-9 $\mu \mathrm{m}$ in horizontal width; vesselray parenchyma pits with reduced borders and rounded to oval in outline (Text-fig. 1e), occasionally irregular in shape, most commonly in upright/square ray cells; prominent helical thickenings along the full length of narrow vessel elements (Text-fig. 1c, d); mean vessel element length 354 (38), range 275-435 $\mu \mathrm{m}$; tyloses abundant, bubble-like in earlywood vessels, more widely spaced in latewood vessels.

Fibers non-septate, walls medium-thick, pitting not observed.

Axial parenchyma rare, scanty paratracheal.

Rays 1-3(-4)-seriate, uniseriates low, usually less than 10 cells high (Text-fig. 1d, g, h). Multiseriate rays heterocellular, body of procumbent cells, with 1-2(4) marginal rows of upright cells (Text-fig. 1e); total multiseriate ray height average 308 (100), range 135-555 $\mu \mathrm{m} ; 4-5 / \mathrm{mm}$. Solitary crystals occasional in upright/square marginal ray cells (Text-fig. 1f, h), some crystalliferous cells enlarged, rarely chambered. Radial canals present (Textfig. 1i), oval in outline, canal size - width by height ranging from $40 \times 70 \mu \mathrm{m}$ to $60 \times 110 \mu \mathrm{m}$, with thin-walled walled epithelial cells.

Comparisons with extant woods. A search of InsideWood for ring-porous wood (3p), vessels in radial multiples of four or more common (10p), simple perforation plates (13p), alternate intervessel pits (22p), vessel-ray parenchyma pits with reduced borders (31p), helical thickenings along the length of the vessel elements (36p 37p), and radial canals (130p) returned five species of Pistacia and Rhus microphylla ENGELM. in the Anacardiaceae. Rhus microphylla has a broad earlywood zone, while Pistacia species have narrow earlywood zones, usually with one discontinuous row (more rarely two rows) of enlarged solitary earlywood pores (Fahn et al. 1986, Terrazas 1994, Abundiz-Bonilla et al. 2004). Consequently, we assign these Post Hammer woods to Pistacia.

Pistacia is a genus of shrubs to small trees with a disjunct distribution (Mabberley 2017). Seven species occur from the Mediterranean basin to Central Asia (P. atlantica Desf., $P$. integerrima J.L.Stewart, $P$. khinjuk Stocks, $P$. lentiscus L., P. palaestina Boiss., P. terebinthus L., P. vera) L., two species occur in eastern Asia ( $P$. chinensis Bunge, $P$. weinmannifolia J.PoIss. ex Franch.), two species are distributed from the southwestern United States to Central America ( $P$. mexicana Kunth, $P$. texana Swingle) (Yi et al. 2008). InsideWood has reference images of Pistacia chinensis (FRI 547, CAFw 8636). P. khinjuk (Lw s.n.), P. lentiscus (SJRw 14465), P. mexicana (FPAw 27837 , MADw 12256), and $P$. palaestina (MADw 26695). The latewood of Pistacia terrazasae does not have a pronounced diagonal or tangential arrangement and thus resembles the latewood of $P$. lentiscus (SJRw 14465) and P. mexicana (MADw 12256) more than the other species which usually have a pronounced tangential to diagonal-dendritic arrangement. Ray widths in this new species also are similar to $P$. lentiscus and $P$. mexicana. According to Terrazas (1994), who examined wood of 10 extant Pistacia species, multiseriate rays in $P$. mexicana and $P$. lentiscus were "most commonly 2-3" cells wide, implying that in other species multiseriate rays usually are 3-5. Appendix I of her dissertation (p. 308) shows the quantitative ray and vessel element features of these two species are similar.

Pistacia lentiscus is found from the Canary Islands across southern Europe from Portugal to Greece and Turkey, across North Africa from Morocco to Egypt and the Middle East; P. mexicana is found in southern Texas, Mexico, Guatemala, and Honduras (AL-Saghir 2010). Both species are evergreen, which is unusual for ring-porous species because ring-porous species almost always are deciduous (Boura and De Franceschi 2007). Yi et al. (2008), using molecular data, placed these two species in section Lentiscus, while AL-Saghir (2010, 2012), using morphological data (almost exclusively leaf characters), placed them in section Lentiscella. Earlier phylogenetic analyses also placed these two widely separated geographically species in the same section (Parfitt and Baldenes 1997).

Comparisons with fossil woods. Dupéron (1973) created the genus Pistacioxylon Dupéron to accommodate a late Eocene/Oligocene wood with features found in ring-porous species of Pistacia. Selected features of the Pistacioxylon species described to date are compared with Pistacia terrazasae (Tab. 1). This Post Hammer wood type and the other species assigned to Pistacioxylon have a combination of wood anatomical features unique to Pistacia. We suggest all could be assigned to Pistacia to indicate that their anatomy is indistinguishable from that of the extant genus. 

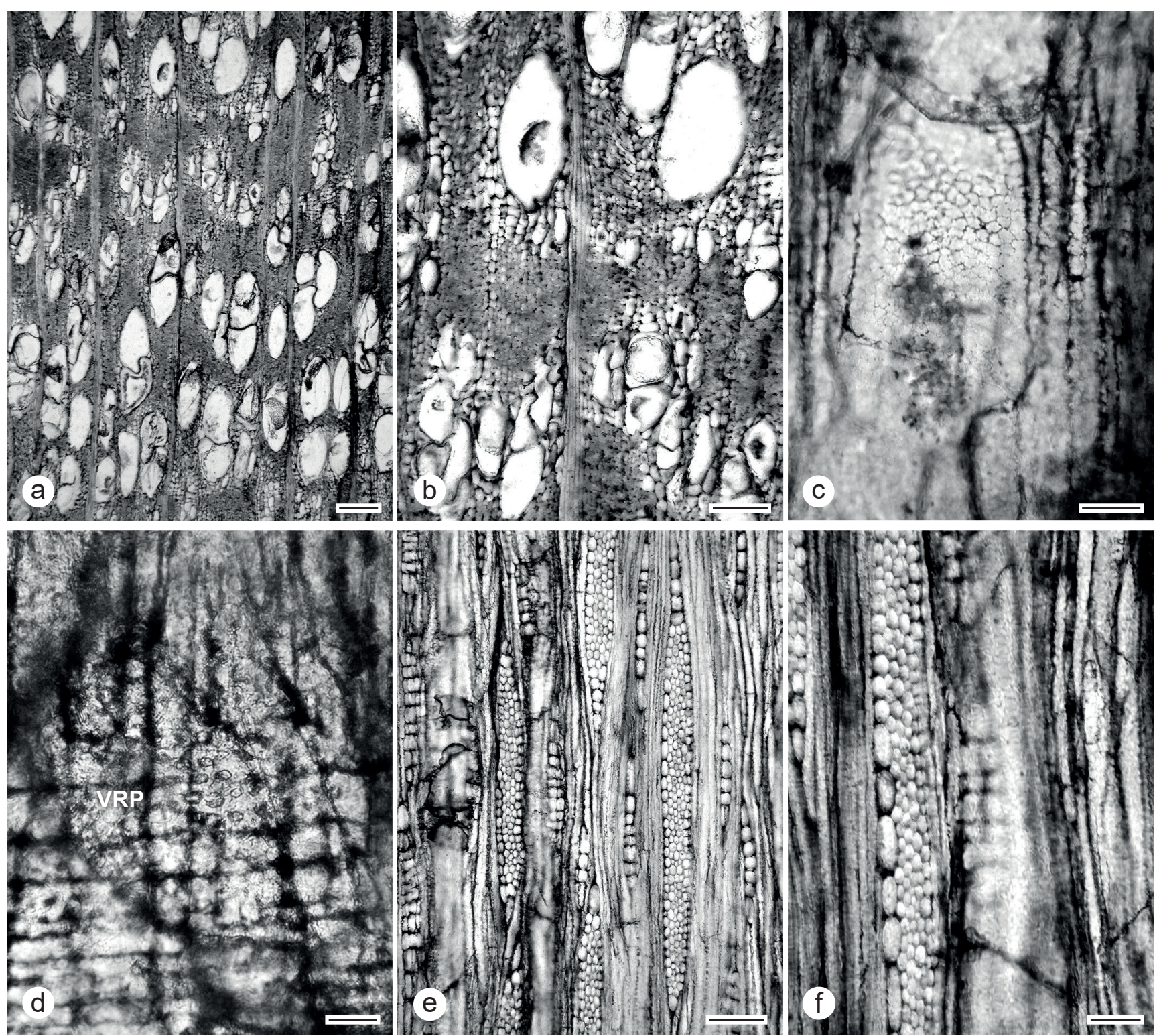

Text-fig. 2. Celtis popsii sp. nov., UF 279-34460. a: Growth ring with earlywood of multiple rows of vessels solitary and in radial multiples; latewood vessels in wavy tangential bands, TS. b: Growth ring boundary, latewood vessels in multiples with axial parenchyma confluent, TS. c: Simple perforation plates, alternate intervessel pits, polygonal in outline, TLS. d: Vessel-ray parenchyma pits to right of VRP, oval in outline, with slightly reduced borders, RLS. e: Rays tending to two sizes, some multiseriate rays with distinct sheath cells, multiseriate rays usually with 1 marginal row of square to upright cells, occasionally with 4 or more; uniseriate rays less than 10 cells high, TLS. f: Detail of multiseriate ray with distinct sheath cells, vessel element end walls, TLS. Scale bars: $200 \mu \mathrm{m}$ in a, e; $100 \mu \mathrm{m}$ in b; $50 \mu \mathrm{m}$ in c, f; $20 \mu \mathrm{m}$ in d.

Co-occurring fruits/seeds. Manchester and McIntosh (2007) illustrated a silica fruit cast with characters similar to those of extant Anacardium L., Cyrtocarpa KunTH, and Pistacia from the same locality (UF 279). It is possible that this wood and that fruit came from the same source plant, given they are the only Anacardiaceae known at locality UF 279. However, without direct attachment between them or repeated co-occurrences this cannot be established. The Nut Beds flora included a fossil fruit, Pistachioides striata MANCHESTER (Manchester 1994), which shares many features with pistachio nuts, but it was not assigned to the modern genus because of insufficient preservation of anatomical details. Although numerous silicified woods are preserved at the Nut Beds, including some Anacardiaceae, none of them resemble Pistacia.
R e m a r k s . Xie et al. (2014) hypothesized that Pistacia originated near the Eocene-Oligocene boundary at 37.60 Ma. The minimum age for the Post sites is $36.21 \pm 0.26 \mathrm{Ma}$ (Manchester and McIntosh 2007), which places Pistacia terrazasae near this hypothesized time of origin. It is the oldest known occurrence of a wood with features of Pistacia and the only one known from the USA. Ramírez and CevallosFerriz (2002) described Pistacia marquezii J.L.RAM. et CEV.FERriz, based on Oligocene leaves (Pie de Vaca Formation, Mexico) and that they thought most similar to present-day $P$. chinensis. They used this similarity to support the concept of exchange between low-latitude North America and Asia. The question remains whether this Oregon fossil wood is evidence for a migration of Pistacia from Asia to Mexico and the American Southwest via the Pacific Northwest. 
Family Cannabaceae Martinov, 1820 nom. cons.

Genus Celtis Tourn. ex L., 1753

Celtis popsii sp. nov.

Text-fig. 2a-f

Holotype. Designated here. UF 279-34460 (Textfig. 2a-f). Minimum estimated axis diameter $28 \mathrm{~cm}$.

Plant Fossil Names Registry Number. PFN002695 (for new species).

Repository. Paleobotany Collections, Florida Museum of Natural History, Gainesville, Florida, USA.

Etymology. Named in honor of Raymond "Pops" Shepherd, who loved and respected the natural beauty of our earth, father of Mark Shepherd, generous supporter of the J. C. Raulston Arboretum.

Type locality. UF 279. About $3 \mathrm{~km}$ east of Post, Crook County, Oregon, USA.

Type stratum and age. John Day Formation, Eocene.

D i a g n o s is. Growth rings distinct, wood ring-porous to semi-ring-porous, earlywood zone with multiple rows of earlywood vessels, latewood vessels in diagonal-tangential arrangement. Perforations simple. Intervessel pitting crowded alternate; vessel-ray pitting oval with reduced borders. Axial parenchyma paratracheal, vasicentric to confluent. Rays $<10$-seriate, heterocellular, sheath cells present.

Description. Growth rings distinct. Wood ringporous to semi-ring-porous.

Earlywood zone 2-4(4+) rows deep with vessels solitary and in radial multiples of 2-3. Latewood vessels in radial multiples and clusters arranged diagonally and in tangential bands (Text-fig. 2a, b). Tangential diameter of earlywood vessels 126 (18), 88-166 $\mu \mathrm{m}$; perforations exclusively simple; intervessel pits crowded alternate, mostly polygonal in outline (Text-fig. 2c), medium-large, 7-11; vessel-ray parenchyma pits oval in outline, not crowded, borders slightly reduced (Text-fig. 2d); vessel element lengths average 380 (141) $\mu \mathrm{m}$; thin-walled bubble-shaped tyloses present.

Fibers mostly non-septate, possibly a few septate, pits not observed, likely thick-walled.

Axial parenchyma vasicentric-confluent (Text-fig. 2a, b), strands mostly of 4 cells.

Rays 1-5(-6) cells wide; tendency to two size classes as $2-3$-seriate rays are rare, sheath cells present in most of the wider rays (Text-fig. 2e, f); heterocellular with procumbent body cells and 1-2(-5) marginal rows of square and upright cells. Multiseriate ray height average 737 (169) $\mu \mathrm{m} ; 4-6 /$ $\mathrm{mm}$. Possibly crystals in somewhat enlarged upright marginal ray parenchyma cells.

Comparisons with extant woods. A search of InsideWood for the combination: wood not diffuse-porous (5e), tangential bands of vessels (6p), simple perforation plates (13p), alternate intervessel pitting that is not small to minute (22p 24a 25a), non-septate fibers (66p), vasicentric parenchyma (79p), heterocellular rays of two size classes (103p 104a 105a) with sheath cells (110p) only returned species of Celtis (Cannabaceae). If vessels in a diagonal arrangement (7p) is used instead of vessels in a tangential arrangement, again only Celtis has that combination of features.

Celtis is a widespread genus with ca. 60 species, mostly trees, that occurs in temperate and tropical regions (Africa, Asia, Central and South America, North America, Southern Europe; Sattarian 2006, Mabberley 2017). InsideWood includes coded descriptions of 25 species and images of 22 species.

There is variation in porosity within the genus, and sometimes within a species, related to geography, climate, and leaf retention. Typically, tropical species are diffuseporous, e.g., C. africana BURM.F., C. gomphophylla BAKER, and $C$. mildbraedii Engl. (Africa) and C. schippii Standl. (Central and South America), while temperate species are ring-porous, e.g., C. laevigata WILlD., C. occidentalis L. (North America), C. bungeana Blume, C. sinensis Pers. (temperate Asia), as well as $C$. australis L. (Mediterranean region). Celtis pallida TorR., a shrub to small tree native to dry regions of southwest North America, extending to Central and South America, is semi-evergreen and diffuseporous to somewhat semi-ring-porous (Sweitzer 1971, Wheeler et al. 1988, Zhong et al. 1992, Wood Identification Database Team, FFPRI accessed 2020-2021, InsideWood 2004-onwards). The Asian C. philippensis BlANCO is diffuse-porous in tropical regions and semi-ring- to ringporous in more seasonal environments (Zhong et al. 1992). One sample each of $C$. laevigata (BWCw 8303, Florida, USA), C. laevigata var. reticulata (TORR.) L.D.BENSON (SJRw 40228, Texas, USA), and $C$. biondii PAMP. (CAFw 20246, Jiangxi, southeast China) were semi-ring-porous, rather than ring-porous.

Present-day ring-porous Celtis species usually have only 1-2 rows of earlywood vessels. However, some samples of C. occidentalis (BWCw 8272; BWCw 8456; FPAw 9598), and $C$. sinensis (TWTw 23448) have multiple rows of earlywood vessels. Ring-porous Celtis generally have wider rays (to 12-seriate) than diffuse-porous species (to 8-seriate, but mostly $1-5$-seriate). The anatomy of this Post Hammer wood with its tendency to semi-ring-porosity and rays to 5-6-seriate suggests it grew in a seasonal environment, but one not as pronounced as North Temperate Celtis species experience today.

Comparisons with fossil woods. Apparently, the three generic names - Celtisoxylon T.TRIVEDI (Trivedi 1971), Celtixylon Greguss (Greguss 1943), Celtoxylon Wurzinger (Wurzinger 1953) - created for fossil woods thought to resemble Celtis - were not properly diagnosed (Gregory et al. 2009). Celtisoxylon was applied to a wood from Deccan Intertrappean beds of India but was only mentioned in an abstract without diagnosis or designation of holotype, Celtixylon was never formally diagnosed, and Celtoxylon was used in a thesis, but not formally published.

Woods thought to have affinities with Celtis have been reported from the Miocene of temperate Europe and Asia. Selmeier $(1989,2015)$ described Celtixylon cristalliferum A.Selm. from the lower and middle Miocene of Germany and compared it to $C$. palaeohungaricum Greguss and 

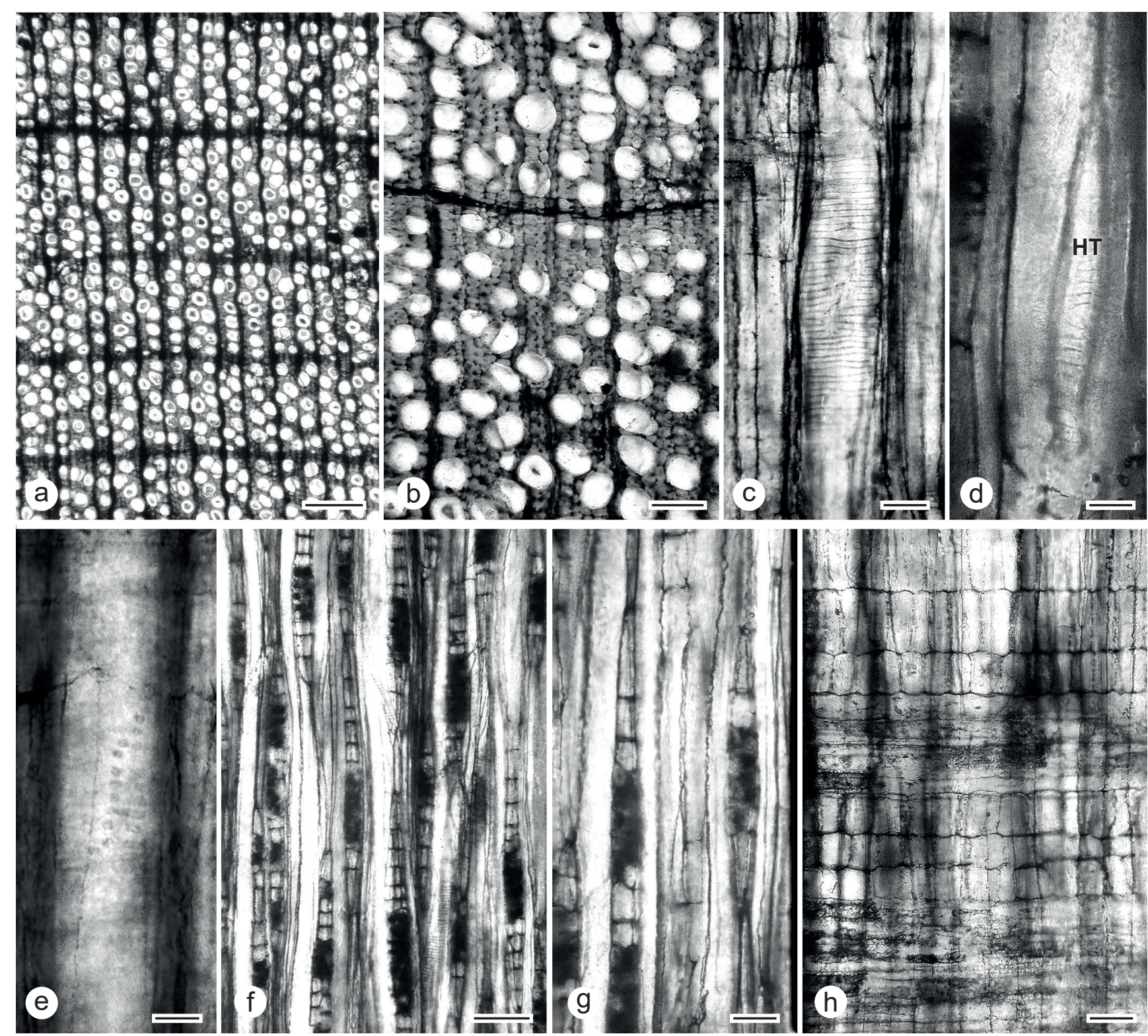

Text-fig. 3. Cercidiphyllum cf. alalongum R.A.ScotT et E.A.WheELER, UF 279-24543. a, b: Diffuse-porous wood, exclusively solitary vessels, axial parenchyma rare, thick-walled fibers, TS. c: Scalariform perforation plate with more than 30 bars, RLS. d: Helical thickenings (HT) in vessel element tip, RLS. e: Opposite to scalariform intervessel pits, RLS. f, g: Heterocellular rays 1-2 cells wide, occasionally uniseriate and biseriate portions of similar width, TLS. h: Ray with alternating rows of procumbent and upright (-square) cells, RLS. Scale bars: $200 \mu \mathrm{m}$ in a; $100 \mu \mathrm{m}$ in b, f; $50 \mu \mathrm{m}$ in c, g, h; $20 \mu \mathrm{m}$ in d, e.

C. campestre (E.Hofm.) Greguss from the Miocene of Hungary. These latter two species had rays up to 10-12 cells wide, while the widest rays of $C$. cristalliferum were 6-7-seriate. Celtixylon cristalliferum differs from Celtis popsii because it has a narrower earlywood pore zone with 1-2 (3) rows of large vessels, less well-defined sheath cells in the rays, and not as obvious a tendency to two size classes of rays. The illustration of the Celtixylon sp. (probable Miocene age) that Gottwald (2004) described also shows only 1-2 rows of large earlywood pores.

As detailed above, Celtis popsii differs from other fossil wood species thought related to Celtis and has wood anatomical features that fall within the range of and are unique to Celtis, so we assign it to the genus. To the best of our knowledge, this is the only fossil Celtis wood known from North America.
Co-occurring fruits/seeds. To date, there is no record of Celtis in the fruit/seed assemblage of locality UF 279.

Family Cercidiphyllaceae EngL., 1907 nom. cons.

Genus Cercidiphyllum Siebold et Zucc., 1846

Cercidiphyllum alalongum R.A.ScOTT et E.A.WHEeLER, 1982

Text-fig. 3a-h

M a t e r i a l. A single specimen (UF 279-24543) with an estimated minimum diameter of $8.8 \mathrm{~cm}$.

Description. Growth rings distinct, marked by bands of radially narrow fibers, difference in vessel diameter between latewood and earlywood vessels of successive rings (Text-fig. 3a, b). Wood diffuse-porous. 
Vessels predominantly solitary (Text-fig. 3a, b), mean tangential diameter 59 (12) $\mu \mathrm{m}, 32-86 \mu \mathrm{m}$; 82-95-102/ $\mathrm{mm}^{2}$; perforations all scalariform, 28-47 fine bars (Textfig. 3c); intervessel pits rare, opposite to scalariform (Textfig. 3e); vessel-ray parenchyma pits scalariform; vessel element lengths 980-1,400 $\mu \mathrm{m}$; tyloses not observed. Faint helical thickenings occasionally observed in vessel element tips (Text-fig. 3d).

Fibers non-septate, thick-walled, small $(2-3 \mu \mathrm{m})$ bordered pits observed on radial walls of some fibers.

Axial parenchyma rare.

Rays 1-2(-3)-seriate, uniseriate portions frequently alternating with multiseriate portions, occasionally width of the uniseriate and multiseriate portions similar (Text-fig. 3f, g), markedly heterocellular with upright cells often $2 \times$ the height of the procumbent cells (Text-fig. 3h), procumbent cells with relatively thick walls and richly pitted, upright and square cells with relatively thin walls; uniseriate rays exclusively of upright and square cells, usually less than 10 cells high; $\sim 12$ rays per $\mathrm{mm}$.

Crystals not observed.

Comparisons with extant woods. The combination of diffuse-porous wood (5p), exclusively solitary vessels $(9 p)$, scalariform perforation plates with more than 20 bars $(17 \mathrm{p})$, opposite-scalariform pits $(22 \mathrm{a}-$ alternate pits absent), narrow numerous vessels (42a 43a 46a $47 \mathrm{a} 48 \mathrm{a}-$ absence of both medium-wide vessels and fewer than 40 vessels per $\mathrm{mm}^{2}$ ), long vessel elements (54p), fibers with bordered pits (62p), axial parenchyma rare-absent $(75 p)$, rays $1-3$-seriate $(97 p)$ and heterocellular rays (104a 105a) occurs in the saxifragalean families Altingiaceae (Liquidambar L.), Cercidiphyllaceae (Cercidiphyllum), and Hamamelidaceae (Corylopsis Siebold et Zucc.). Sakala and Privé-Gill (2004) discussed how to distinguish woods of these three genera and concluded that Cercidiphyllum consistently had more bars per perforation plate (to $>40$ bars) than the other two genera. Based on their criteria this wood has affinities with the Cercidiphyllaceae. Scott and Wheeler (1982) detailed differences between the ray structure of Cercidiphyllum and Corylopsis: rays in Cercidiphyllum have more than two alternating 1-seriate and 2-3-seriate portions and in some rays the 1 -seriate and 2-3-seriate portions are of equal width.

Comparisons with fossil woods. Sakala and Privé-Gill (2004) reviewed the occurrences of Cercidiphyllum-like wood and recognized only two species: Cercidiphylloxylon kadanense U.PrAKASH, BŘEzINOVÁ et BŮžEK (Prakash et al. 1971) from the Czech Republic, and Cercidiphylloxylon spenceri (D.W.BRETt) H.L.PEARson from the Paleocene of Scotland and the Eocene London Clay (Brett 1956, Pearson 1987). Subsequently, Guo et al. (2010) assigned a sample from the Paleocene of China to Cercidiphylloxylon spenceri, and again reviewed the occurrences and criteria for recognizing wood of Cercidiphyllaceae.

Pearson (1987) and Crawley (1989) suggested the Clarno Nut Beds wood Cercidiphyllum alalongum R.A.ScotT et E.A.WHEELER (Scott and Wheeler 1982) should be included in Cercidiphylloxylon spenceri (Pearson 1987). Ray structure is notorious for its variability, especially differences between juvenile wood and mature wood. Nonetheless, we consider the Nut Beds Cercidiphyllum distinct from the European Cercidiphyllum-like woods, which do not have alternating uniseriate and multiseriate parts. The Chinese sample does, but the parts are not of equal width. Helical thickenings in vessel element tails were not reported for the European or Chinese woods. Admittedly, the preservation of those specimens does not appear to be as good as the Oregon specimens, so helical thickenings might have been difficult to observe.

Remarks. Leaves and fruits with features unique to Cercidiphyllum are not known prior to the Oligocene, although extinct genera attributed to the family are widespread in the Paleocene and Eocene (e.g., Crane and Stockey 1985). This was a major part of the rationale Sakala and PrivéGill (2004) used for assigning the Nut Beds and London Clay Cercidiphyllum-like woods to Cercidiphylloxylon, i.e., these Eocene woods predate the occurrence of "real" Cercidiphyllum. However, the Oligocene Cercidiphyllumlike woods, which are of an age when there is "real" Cercidiphyllum also were placed in Cercidiphylloxylon. It is a matter of opinion, but we do not think there are significant anatomical differences between the Paleocene, Eocene, or Oligocene Cercidiphyllum-like woods and present-day Cercidiphyllum and do not think it necessary to assign the Paleogene woods to Cercidiphylloxylon rather than Cercidiphyllum. This "disconnect" between fossil woods resembling the present-day Cercidiphyllum and fruits that do not may be an example of mosaic evolution within the Cercidiphyllaceae.

Co-occurring fruits/seeds. By "real" Cercidiphyllum, we refer to occurrences of fruits with follicles borne in sessile clusters, in association with leaves closely resembling those of extant Cercidphyllum japonicum. Such fossils occur only a few $\mathrm{km}$ from the UF 279 wood locality, but in overlying strata considered to be lower Oligocene (Meyer and Manchester 1997). Brown (1935) used a broader concept of the genus Cercidiphyllum, incorporating fossil infructescences with fruits borne in racemes rather than clusters, associated with Trochodendroides E.W.BERRY leaves which are similar to the leaves of extant Cercidiphyllum. Today such infructescences are usually placed in the extinct genus Jenkinsella E.REID et M.ChAndLer (syn. Nyssidium auct non HeER) (Golovneva and Alekseev 2017). In Central Oregon, Jenkinsella infructescences are known from the Hancock Canyon site (Wheeler and Manchester 2014).

Fagaceae Dumort., 1829

Genus Fagus Tourn. ex L., 1753

Fagus dodgei sp. nov.

Text-fig. $4 \mathrm{a}-\mathrm{h}$

Hol oty pe. Designated here. UF 279-34468 (Textfig. $4 \mathrm{a}, \mathrm{b}, \mathrm{d}-\mathrm{h})$. Minimum estimated axis diameter $10 \mathrm{~cm}$.

Additional material. UF 279-30165 (Textfig. 4c).

Plant Fossil Names Registry Number. PFN 002679 (for new species). 

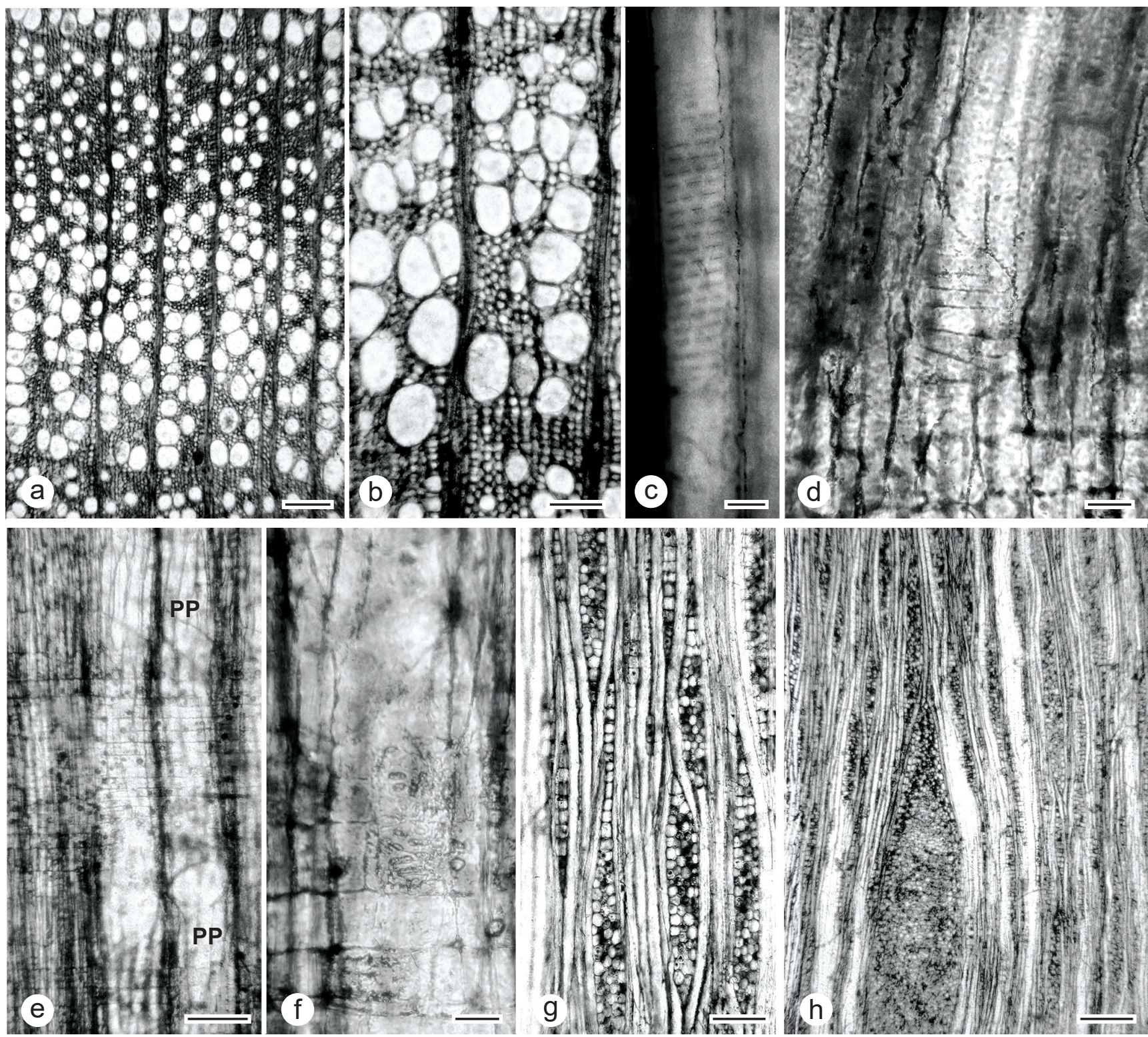

Text-fig. 4. Fagus dodgei sp. nov., a, b, d-h: UF 279-34468; c: UF 279-30165. a: Wood diffuse-porous to semi-ring-porous with distinct latewood zone with narrower vessels; vessels solitary and in short multiples; diffuse, diffuse-in-aggregates axial parenchyma visible in latewood, TS. b: Growth ring boundary, TS. c: Opposite intervessel pitting, TLS. d: Scalariform perforation plate with fewer than 10 bars, RLS. e: Simple perforation plates (PP), RLS. f: Vessel-ray parenchyma pitting with reduced borders and frequently oval in outline, RLS. g: Rays 1-4(-5)-seriate with variable numbers of marginal rows, TLS. h: Rays of two distinct sizes, widest rays $>10$-seriate, TLS. Scale bars: $200 \mu \mathrm{m}$ in a, $\mathrm{h} ; 100 \mu \mathrm{m}$ in b, e, g; $50 \mu \mathrm{m}$ in d, f.

Repository. Paleobotany Collections, Florida Museum of Natural History, Gainesville, Florida, USA.

E ty m o log y. Named for William W. Dodge IV, who made sure paleoxylotomy in North Carolina was alive and well during the Covid-19 pandemic.

Type locality. UF 279. About $3 \mathrm{~km}$ east of Post, Crook County, Oregon, USA.

Type stratum and age. John Day Formation, Eocene.

Diagnosis. Growth rings distinct. Diffuse-porous to semi-ring-porous. Vessels mostly solitary, but also in occasional radial, oblique, or tangential pairs; tangential diameters average $<100 \mu \mathrm{m}$; perforations simple and scalariform; intervessel pits opposite, transitional to scalariform; pits to ray parenchyma oval to horizontally elongate, with reduced borders. Non-septate fibers with distinctly bordered pits on radial walls. Axial parenchyma diffuse and diffuse-in-aggregates as short uniseriate bands. Rays uniseriate and multiseriate, tending to be of two sizes, wider multiseriate rays $>10$-seriate; wide rays irregularly spaced; average multiseriate ray height $>1 \mathrm{~mm}$; homocellular to heterocellular, body composed of procumbent cells with marginal rows of square and upright cells. Solitary rhomboidal crystals occasional in procumbent ray cells. Storied structure absent.

Description. Growth rings distinct, marked by radially narrow fibers, and differences between latewood and earlywood vessels of subsequent rings (latewood vessels are narrower and not as crowded as earlywood vessels) (Textfig. 4a, b). Diffuse-porous to semi-ring-porous (Text-fig. 4a). 
Vessels mostly solitary, but also occasional radial, oblique and tangential pairs; average earlywood tangential diameter 55 (11), range 39-79 $\mu \mathrm{m}$; vessel frequency in first half of growth ring ca. $90 / \mathrm{mm}^{2}$; perforations simple and scalariform with 4-24 bars, mostly 8-12 bars (Textfig. $4 \mathrm{~d}, \mathrm{e})$; intervessel pits opposite $(5-7 \mu \mathrm{m})$, transitional to scalariform (Text-fig. 4c); pits to ray parenchyma oval to horizontally elongate, with reduced borders (Text-fig. 4f); vessel element lengths $450-520 \mu \mathrm{m}$.

Non-septate fibers with distinctly bordered pits on radial walls.

Axial parenchyma apotracheal, diffuse as isolated cells and diffuse-in-aggregates as short uniseriate bands, more easily seen in latewood (Text-fig. 4a).

Rays uniseriate and multiseriate, tending to be of two sizes, with rays $1-5(-6)$-seriate common, and wider multiseriate rays to 18-20-seriate, with few intermediate widths; wide rays irregularly spaced (Text-fig. $4 \mathrm{~g}, \mathrm{~h}$ ); average multiseriate ray height $1.56 \mathrm{~mm}$, range $0.74-2.69 \mathrm{~mm}$; homocellular to heterocellular, body composed of procumbent cells usually with 1-4 (up to 8) marginal rows of square and upright cells.

Solitary rhomboidal crystals occasional in procumbent ray cells. Storied structure absent.

Comparisons with extant woods. The following combination of features indicates affinities with Fagus (Fagaceae): distinct growth rings (1p), simple and scalariform perforation plates (13p 14p), opposite intervessel pitting (21p), vessel-ray parenchyma pits with reduced borders (30a), narrow numerous vessels (42a 43a 46 a 47a), non-septate fibers with distinctly bordered pits on radial walls (62p 66p), diffuse and diffuse-in-aggregates axial parenchyma (76p 77p), wide rays $>10$ cells wide and $>1$ mm high (99p 102p). To the best of our knowledge, there is not a reliable means of distinguishing present-day Fagus species based on wood anatomy alone (Brazier and Franklin 1961, Wheeler and Dillhoff 2009).

Woods of the Platanaceae are common in the Paleogene of the western USA. and superficially resemble Fagus. However, there are features useful in distinguishing them (e.g., Panshin and DeZeeuw 1980, Hoadley 1990). Fagus consistently has vessel-ray parenchyma pits with reduced borders that are somewhat horizontally elongate, while Platanus L. has vessel-ray parenchyma pits similar to intervessel pits. Vessel multiples are rare in both, but Platanus has some tangential multiples and a tendency to vessels being tangentially arranged; consequently, intervessel pits are more common in Platanus than in Fagus. Intervessel pits are consistently opposite in Platanus; while Fagus usually has transitional (opposite- scalariform) intervessel pitting. Spacing of and size of the wide rays is more uniform in Platanus than in Fagus. All these features can be reviewed in the InsideWood image collection (InsideWood 2004-onwards).

Comparisons with fossil woods. Faguslike woods have been described as species of Fagus, Fagoxylon Stopes et FujI, and Fegonium Unger (Süss 1986). Descriptions of most lack details that would permit confirming their relationships with Fagus. There are at least ten Fagus-like woods reported from the Mio-Pliocene of Europe (Gregory et al. 2009), but their descriptions are brief, so it is not possible to do detailed comparisons of them with this late Eocene wood.

There are differences between Fagus dodgei and the midMiocene Fagus manosii E.A.WheEler et T.A.Dillhoff from Washington State, USA (Wheeler and Dillhoff 2009), which had more scalariform intervessel pits and larger opposite intervessel pits, narrower and shorter rays (to 16-seriate and $1.7 \mathrm{~mm}$ high), less axial parenchyma, and lacked crystals. Thus, although there is no reliable way to distinguish between extant species of Fagus, we are choosing to recognize Fagus dodgei as a new species to emphasize that it differs from the mid-Miocene Vantage Fagus wood.

R e marks. Denk and Grimm (2009) proposed that Fagus evolved in the Northern Pacific Region. Fossil species of Fagus, based on fruits and leaves, are known from the Paleogene of the Pacific Northwest. The middle Eocene Fagus langevinii MANChESTER et R.M.Dillhoff from McAbee, British Columbia, and Republic, Washington, differs from the early Oligocene Fagus pacifica R.W.CHANEY from the Bridge Creek flora of Oregon (Manchester and Dillhoff 2004).

Co-occurring fruits. A single silicified Fagus nut was recovered from the same locality, UF 279 (Manchester and McIntosh 2007).

\section{Genus Lithocarpoxylon Iust.Petrescu, 1978 emend. by Suzuki and Ohba (1991)}

\section{Lithocarpoxylon ashwillii sp. nov.} Text-fig. 5a-g

Holotype. Designated here. UF 279-24559 (Textfig. $5 \mathrm{a}-\mathrm{g})$.

Plant Fossil Names Registry Number. PFN 002680 (for new species).

Repository. Paleobotany Collections, Florida Museum of Natural History, Gainesville, Florida, USA.

Type locality. UF 279. About $3 \mathrm{~km}$ east of Post, Crook County, Oregon, USA.

Type stratum and age. John Day Formation, Eocene.

E t y m o l o g y. Named for Melvin Ashwill, who alerted S. R. Manchester to these woods.

D i a g n o s is. Growth rings distinct. Semi-ring-porous to diffuse-porous. Exclusively solitary vessels in a diagonal to radial arrangement. Simple perforation plates. Vesselray parenchyma pits with reduced borders, often vertically elongate. Vasicentric tracheids present. Axial parenchyma diffuse, diffuse-in-aggregates and in uniseriate lines. Nonseptate fibers. Uniseriate rays and aggregate rays composed of loosely associated narrow rays.

Description. Minimum estimated diameter of $30 \mathrm{~cm}$.

Growth rings distinct. Semi-ring-porous.

Vessels in diagonal to radial alignment; exclusively solitary, round to oval in outline (Text-fig. 5a, b), mean tangential diameter of the earlywood vessels (first three rows) 208 (28)-215 (39) $\mu \mathrm{m}, 160-260 \mu \mathrm{m}$. Simple perforation 

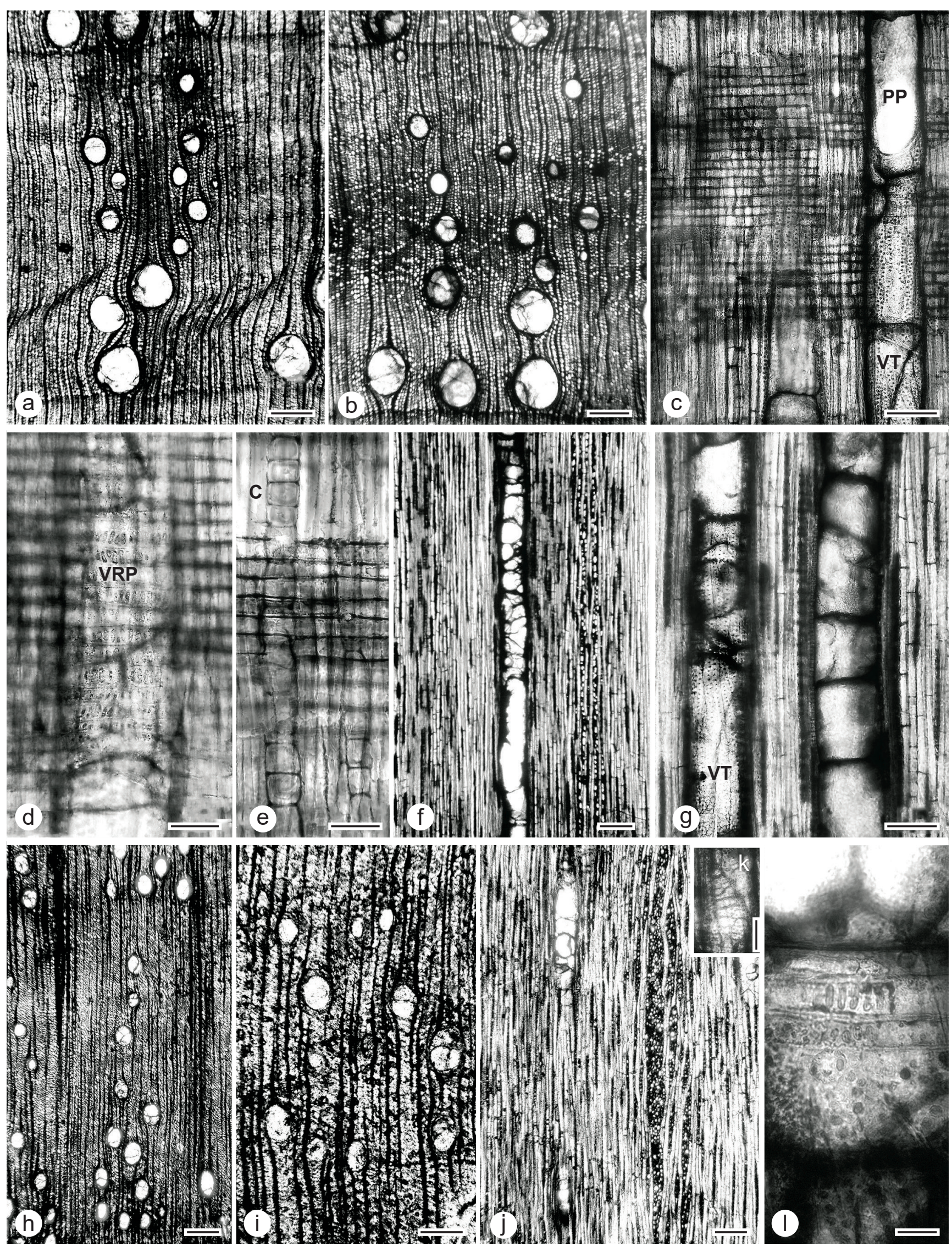

Text-fig. 5. Lithocarpoxylon ashwillii sp. nov., UF 279-24544. a, b: Semi-ring porous wood, exclusively solitary vessels in a radial/ diagonal arrangement, diffuse axial parenchyma, TS. c: Homocellular rays composed of procumbent cells; vasicentric tracheids; vessel elements with simple perforation plates (PP), TLS. d: Vessel-ray parenchyma pits (VRP) with reduced borders, vertical, RLS. e: Crystalliferous axial parenchyma strand (C) with a single crystal per chamber; ray with procumbent cells, RLS. f: Aggregate ray (right) composed of loosely associated 1-2-seriate rays, TLS. g: Uniseriate rays, thin-walled tyloses in vessels, vasicentric tracheids (VT). Lithocarpoxylon sp., UF 279-84864. h, i: Semi-ring porous wood, exclusively solitary vessels in radial arrangement. j: Aggregate ray and uniseriate rays. k: Scalariform perforation plate with fewer than $\mathbf{1 0}$ bars. I: Vessel-ray parenchyma pits with reduced borders to simple, vertical. Scale bars: $200 \mu \mathrm{m}$ in a, b, f, h, j; $100 \mu \mathrm{m}$ in c, i; $50 \mu \mathrm{m}$ in d. e; $20 \mu \mathrm{m}$ in k, l. 
plates (Text-fig. 5c, d), end walls of vessel elements usually horizontal (Text-fig. 5g). Vessel-ray parenchyma pits with reduced borders and commonly vertically elongated (Textfig. 5d). Thin-walled tyloses common in wider vessels.

Non-septate fibers of medium wall thickness. Some with small (ca. $3 \mu \mathrm{m}$ ) bordered pits on radial walls. Vasicentric tracheids present (Text-fig. 5c, g).

Axial parenchyma apotracheal diffuse, diffuse-inaggregates, and in 1-seriate lines (Text-fig. 5a, b), 4-8 cells per strand.

Rays uniseriate (Text-fig. 5f, g), homocellular composed of procumbent cells and heterocellular with some square and upright cells; upright and square cells more common in region of vessels. Some loosely aggregate rays composed of 1-2(-3)-seriate rays (Text-fig. 5f). Rays 2-15-47 cells high; uniseriate rays $12-15-18 / \mathrm{mm}$.

Solitary prismatic crystals occasional in chambered axial parenchyma, 1 crystal per chamber, number of chambers 2-10 (Text-fig. 5e).

Comparisons with extant woods. The affinities of this wood are clearly with the Fagaceae because of the combination of semi-ring-porosity (4p), exclusively solitary vessels that are in a radial to diagonal arrangement ( $7 p 9 p)$, vertical vessel-ray parenchyma pits with reduced borders (32p), vasicentric tracheids (60p), and aggregate rays $(101 \mathrm{p})$.

Aggregate rays are rare in this fossil and comprised of loosely associated narrow rays, similar to rays of Notholithocarpus densiflorus (HoOK. et ARN.) MANOs, CANNON et S.H.OH (synonym: Lithocarpus densiflorus (Hook. et ARn.) ReHDER) (BWCw 8593). Images in InsideWood, the on-line FFPRI Database of Japanese Woods (Wood Identification Database Team, FFPRI accessed 2020-2021), and wood anatomical atlases (Ilic 1991, Ogata et al. 2008) indicate that aggregate rays in the evergreen oaks and Lithocarpus BLUME species are more common and composed of considerably wider individual rays. Two samples of Castanopsis (D.Don) SPACH (TWTw 22503, TWTw 15003) have aggregate rays composed of 1-3-seriate rays, but they were more closely associated than in this fossil. It is tempting to consider that this fossil might have affinities with Notholithocarpus MANOS, CANNON et S.H.ОH, a western North America endemic, found to be more closely related to Castanopsis than to Lithocarpus (Manos et al. 2008). However, we only saw a small sampling of the hundreds of extant species of evergreen oaks, Castanopsis, and Lithocarpus, so we cannot be certain of that relationship.

Comparisons with fossil woods. In their useful overview of Quercus L. and Quercus-like fossil woods, Suzuki and Ohba (1991) emended the diagnosis of Lithocarpoxylon (Petrescu 1978) and indicated that this name should be applied to fagaceous woods that are diffuse to semi-ring-porous, with radially arranged pores, and aggregate rays. They noted that this combination occurred not only in Lithocarpus, but in evergreen species of Quercus and tropical species of Castanopsis. We are following Suzuki and Ohba's recommendation and assigning this Post Hammer wood to Lithocarpoxylon. To the best of our knowledge, no other Lithocarpoxylon has aggregate rays composed of such loosely associated 1-2-seriate rays, so we designate it a new species. Selmeier and Velitzelos (2000) described evergreen oak types; transverse sections of two of their samples (15 and 20) suggest the possibility of similar aggregate rays, but, unfortunately, there were no tangential sections provided for verification.

\section{Lithocarpoxylon sp.}

Text-fig. $5 \mathrm{~h}-1$

\section{M a teria l. UF 279-84864.}

Description. Growth rings indistinct to distinct. Semi-ring-porous to diffuse-porous.

Vessels in radial to slightly diagonal alignment; exclusively solitary, round to oval in outline (Text-fig. 5h, i), mean tangential diameter of the vessels in the first half of the growth ring $122(22) \mu \mathrm{m}, 67-166 \mu \mathrm{m}$. Predominantly simple perforation plates, one scalariform perforation plate with fewer than 10 bars observed (Text-fig. 5k). Vesselray parenchyma pits with reduced borders and commonly vertically elongated (Text-fig. 51). Thin-walled tyloses common.

Axial parenchyma apotracheal diffuse, diffuse-inaggregates (Text-fig. 5h, i), 4-8 cells per strand.

Vasicentric tracheids present (Text-fig. 5j, 1).

Rays uniseriate and aggregate (Text-fig. 5j), homocellular composed of procumbent cells. Aggregate rays composed of 1-8-seriate rays, loosely associated (Text-fig. 5j). Uniseriate rays $3-11-16$ cells high; uniseriate rays $>12$ per $\mathrm{mm}$.

Crystals not observed.

Comparisons with extant woods. The rationale for assigning this sample to Lithocarpoxylon is the same as that for UF 279-24559 described above. This sample differs in having more frequent aggregate rays composed of wider individual rays and narrower vessels.

Comparisons with fossil woods. Most other species of Lithocarpoxylon, with the notable exception of Lithocarpoxylon microporosum Y.M.CHENG, Y.F.WANG, F.X.Liu, R.C.Mehrotra, X. M.Jiang, C.S.Li et Y.G.Jin from the Pliocene of Yunnan, China (Cheng et al. 2018), have wider vessels than this Post Hammer wood; most also have rays greater than 10 cells wide or compound rays. For now, we are hesitant to assign this wood to a new species based on differences in quantitative features.

\section{Genus Quercus L., 1753}

\section{Quercus sp. Red oak group} Text fig. 6a-g

M a terial. UF 279-24550.

D e s c ri pti o n. Growth rings distinct. Ring-porous to semi-ring-porous.

Vessels exclusively solitary, latewood vessels in diagonal to radial alignment (Text-fig. 6a, b), round to occasionally oval in outline, mean tangential diameter of earlywood vessels 199 (28), 124-244 $\mu \mathrm{m}$; perforations simple (Textfig. 6e); vessel-vasicentric pits alternate, rounded in outline (Text-fig. 6d), $\sim 9-10 \mu \mathrm{m}$; vessel-ray parenchyma pits with reduced borders, horizontally to vertically elongate, variable (Text-fig. 6e); vessel element lengths 275-325 $\mu \mathrm{m}$. Thinwalled tyloses present. 

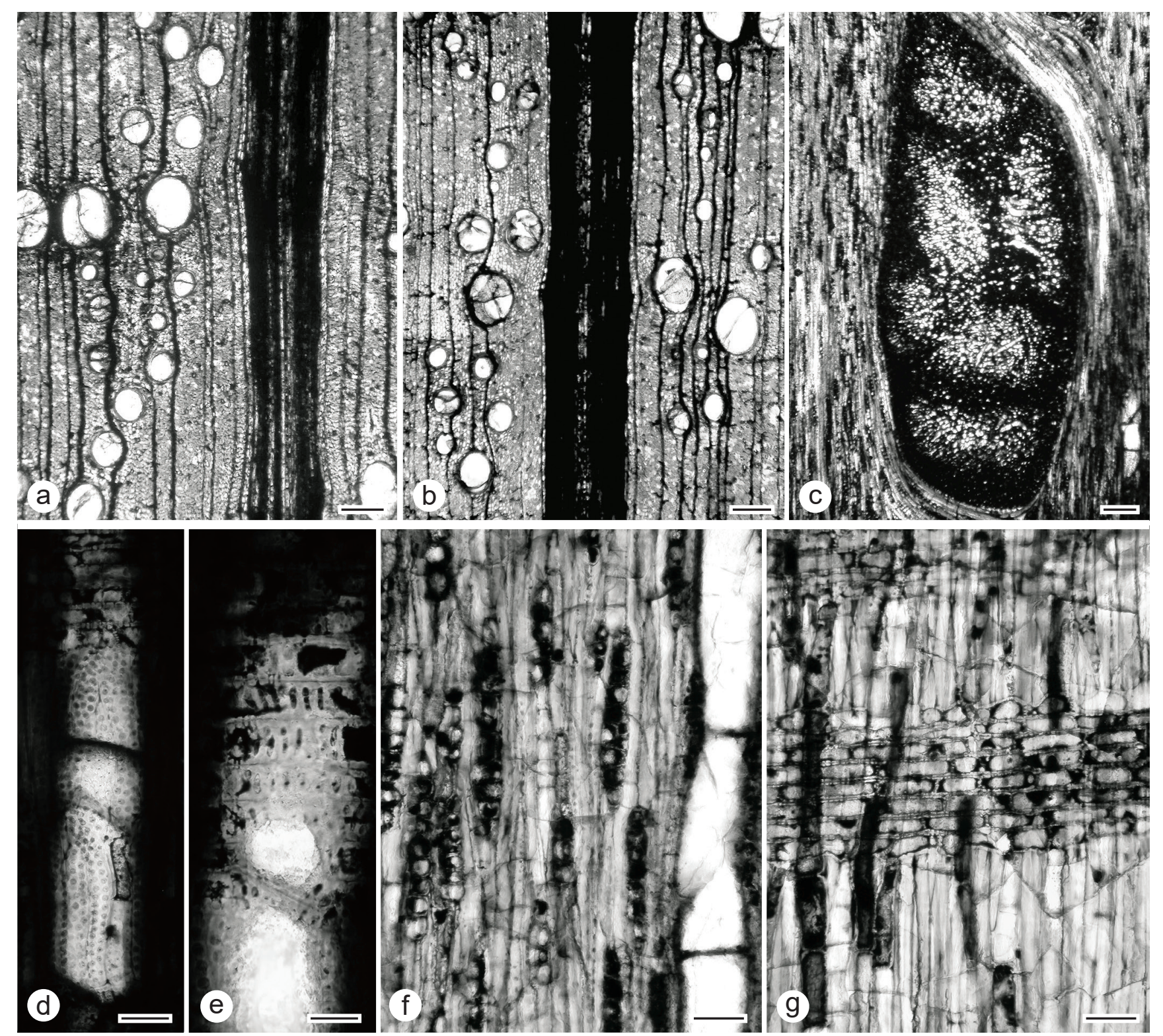

Text-fig. 6. Quercus sp. Red Oak, UF 279-24550. a, b: Wood semi-ring-porous to diffuse-porous; vessels exclusively solitary; thinwalled tyloses in wide vessels; diffuse, diffuse-in-aggregates axial parenchyma; rays of two distinct sizes. TS. c: Rays of two distinct sizes, TLS. d: Vessel-vasicentric tracheid pitting, RLS. e: Vessel-ray parenchyma pitting with reduced borders, vertically elongate, RLS. f: Narrow rays 1-2 cells wide, TLS. g: Ray composed of procumbent cells, RLS. Scale bars: $200 \mu \mathrm{m}$ in $\mathbf{a}, \mathrm{b}$, c; $50 \mu \mathrm{m}$ in d, $\mathbf{f}, \mathbf{g} ; 20 \mu \mathrm{m}$ in e.

Imperforate tracheary elements include vasicentric tracheids (Text-fig. 6d), and non-septate fibers with thick walls.

Axial parenchyma apotracheal, relatively abundant, diffuse, diffuse-in-aggregates, and in 1-seriate lines (Textfig. $6 a, b)$; strands of 4 cells.

Rays of two distinct sizes (Text-fig. 6a, b, c), uniseriate (rarely with biseriate portions) (Text-fig. 6f) and wide rays $38-62$ cells wide, $0.49-1.1 \mathrm{~mm}$; some wide rays with areas of cells of differing wall thicknesses and some with imperforate elements, probably beginning of ray dissection; homocellular, composed of procumbent cells (Text-fig. 6g); uniseriate rays $2-7-15$ cells high; numerous 8-12-14 per mm.

Crystals occasional in chambered axial parenchyma strand, usually less than 4-chambers.
Comparisons with extant woods. This wood has features of the Castaneioideae (e.g., Wheeler et al. 2022): vessels exclusively solitary in radial/diagonal, vasicentric tracheids, vessel-ray parenchyma pits with reduced borders, homocellular rays of two distinct sizes, apotracheal parenchyma. Because the latewood vessels are rounded in outline, this wood is assigned to the Red Oak group, Quercus sect. Lobatae Loudon; latewood vessels in the White Oak group are angular in outline (e.g., Brazier and Franklin 1961, Panshin and DeZeeuw 1980). Distinguishing species in the Red Oak Group based on wood anatomy is not feasible, so we are only designating it as Quercus sp. Red Oak Group.

Comparisons with other fossil woods. This ring-porous to semi-ring-porous wood differs from the Nut Beds Quercinium crystallifera R.A.ScotT et 
E.A.WHEELER, which is diffuse to semi-ring-porous. Other differences are that UF 279-24550 has exceptionally wide rays, its rays are not typically aggregate, and crystals are not common. Reports of fossil oak woods are quite common in the literature, with different species reflecting differences in age and locality as much as differences in anatomy (e.g., Müller-Stoll and Mädel 1957, Suzuki and Ohba 1991).

Co-occurring fruits. Manchester and McIntosh (2007) illustrated an oblate nut covered in whorls of scales and preserved as a silica cast lacking internal anatomy from locality UF 279 (figs 37-39) that was interpreted as representing an acorn of Quercus with the nut fully enclosed by the cupule.

\section{Family Hamamelidaceae R. BR., 1818 nom. cons.}

\section{Genus Hamamelidoxylon LigN., 1907}

\section{Hamamelidoxylon crystalliferum sp. nov.} Text-fig. $7 \mathrm{a}-\mathrm{i}$

Hol otype. Designated here. UF 279-34464 (Textfig. 7a-i). Minimum estimated axis diameter $15 \mathrm{~cm}$.

Paratype. UF 279-24555 (minimum estimated diameter $30 \mathrm{~cm})$.

Plant Fossil Names Registry Number. PFN002681 (for new species).

Repository. Paleobotany Collections, Florida Museum of Natural History, Gainesville, Florida, USA.

Type locality. UF 279. About $3 \mathrm{~km}$ east of Post, Crook County, Oregon, USA.

Type stratum and age. John Day Formation, Eocene.

E t y m o log y. Named for crystals in this wood.

$\mathrm{D}$ i a g n o s is . Growth rings distinct to indistinct. Wood diffuse-porous. Vessels predominantly solitary, narrow, and numerous. Perforation plates exclusively scalariform, fewer than 20 bars per perforation plate. Intervessel pitting scalariform. Vessel-ray parenchyma pits with reduced borders and horizontally elongate. Fibers non-septate, with bordered pits on radial walls. Axial parenchyma rare. Heterocellular rays, 1-2 cells wide. Solitary prismatic crystals in chambered and non-chambered square to upright ray cells, crystal-containing cells somewhat inflated.

Description. Growth rings boundaries distinct to indistinct, marked by a few rows of radially narrow fibers, with latest latewood vessels narrower than the first earlywood vessels (Text-fig. 7a, b). Wood diffuse-porous.

Vessels predominantly solitary, angular in outline (Textfig. 7a, b), mean tangential diameter 43 (8)-47(6); 104 $149 \mathrm{~mm}^{2}$; perforations all scalariform, 11-15 bars (Textfig. 7e); intervessel pits scalariform (Text-fig. 7c); vessel-ray parenchyma pits horizontally elongated (Text-fig. 7f), vessel element lengths 690-950 $\mu \mathrm{m}$.

Fibers non-septate, medium-thick to thick walled; distinctly bordered pits on radial walls and tangential walls (Text-fig. 7c, f).

Axial parenchyma rare.
Rays 1-2(-3)-seriate, heterocellular, uniseriate and biseriate portions occasionally alternating, but not commonly (Text-fig. 7f, g); width of uniseriate portions usually not the same as the biseriate portions; uniseriate rays composed of upright cells, biseriate portions of rays composed of procumbent cells, with uniseriate portions of 1-4 (or more) rows of upright cells, upright cells at least $4 \times$ higher than the procumbent cells (Text-fig. $7 \mathrm{~h}$ ).

Solitary crystals occasional in chambered (2-3) upright ray cells, crystalliferous cells usually inflated (Text-fig. 7i).

Comparisons with extant woods. In InsideWood, the combination of diffuse-porous woods (5p), narrow, numerous vessels (42a 43a 47a 48a) that are predominantly solitary $(9 p)$, exclusively scalariform perforation plates (13a 14p), scalariform intervessel pits (20p), vessel-ray parenchyma pits horizontally elongate with reduced borders (32p), axial parenchyma rare (75p), fibers with distinctly bordered pits $(62 p)$, heterocellular 1-2-seriate rays (97p 104a 105a), and crystals in chambered upright ray cells (140p) is unique to the Hamamelidaceae, occurring in Corylopsis, Eustigma GARDNER et ChAmp., Sinowilsonia Hemsl. (subfamily Hamamelidoidieae), and Mytilaria Lecomte (subfamily Mytilariodeae). Of these, Sinowilsonia is the most similar because of its lower number of bars per perforation plate $(<20)$ compared to the three other genera.

The anatomy of extant Hamamelidaceae has been reviewed by Tang (1943), Skvortsova (1975), and Wheeler et al. (2010). The growth ring boundaries resemble those seen in evergreen Asian species of the family (e.g., Chunia H.T.CHANG, Exbucklandia R.W.BR.) more than those of deciduous species.

Comparisons with fossil woods. Lignier's (1907) diagnosis of the genus Hamamelidoxylon includes these features: rays numerous, rays uniseriate, rarely biseriate, vessels predominantly solitary, scalariform perforation plates, axial parenchyma rare. His plate XX (line drawings of $H$. renaulti LigN.) shows a perforation plate with over 25 bars, horizontally elongate vessel-ray parenchyma pitting, ray cell walls with abundant pitting as seen in radial sections, and thick-walled fibers. Subsequently, woods with rays 1-2(-3) cells wide were assigned to the genus, e.g., the European species: H. castellanense GramBAST-FesSARD (GrambastFessard 1969), H. daphniphylloides H.GotTwaLd (Gottwald 1992), and H. rhenamum Burgh (van der Burgh 1973). The genus has been used for woods that have characteristics of the family, but not necessarily of the genus Hamamelis L.

Three species of Hamamelidoxylon have been described from the Pacific Northwest of North America: H. uniseriatum E.A.Wheeler et Manchester from the middle Eocene Clarno Formation (Wheeler and Manchester 2002, 2014) whose characteristics best fit the Tribe Exbucklandiodeae, and $H$. beckii E.A.WheEler et T.A.Dillhoff and $H$. suzukii E.A.WheEler et T.A.Dillhoff from the middle Miocene Vantage Forests, Washington (Wheeler and Dillhoff 2009). Table 2 compares $H$. crystalliferum to them and to the European and Asian Hamamelidoxylon species that have reasonably complete descriptions. The data in the table show that $H$. crystalliferum's combination of 15 or fewer bars per perforation plate, rays $1-2(-3)$ cells wide, and crystals in 

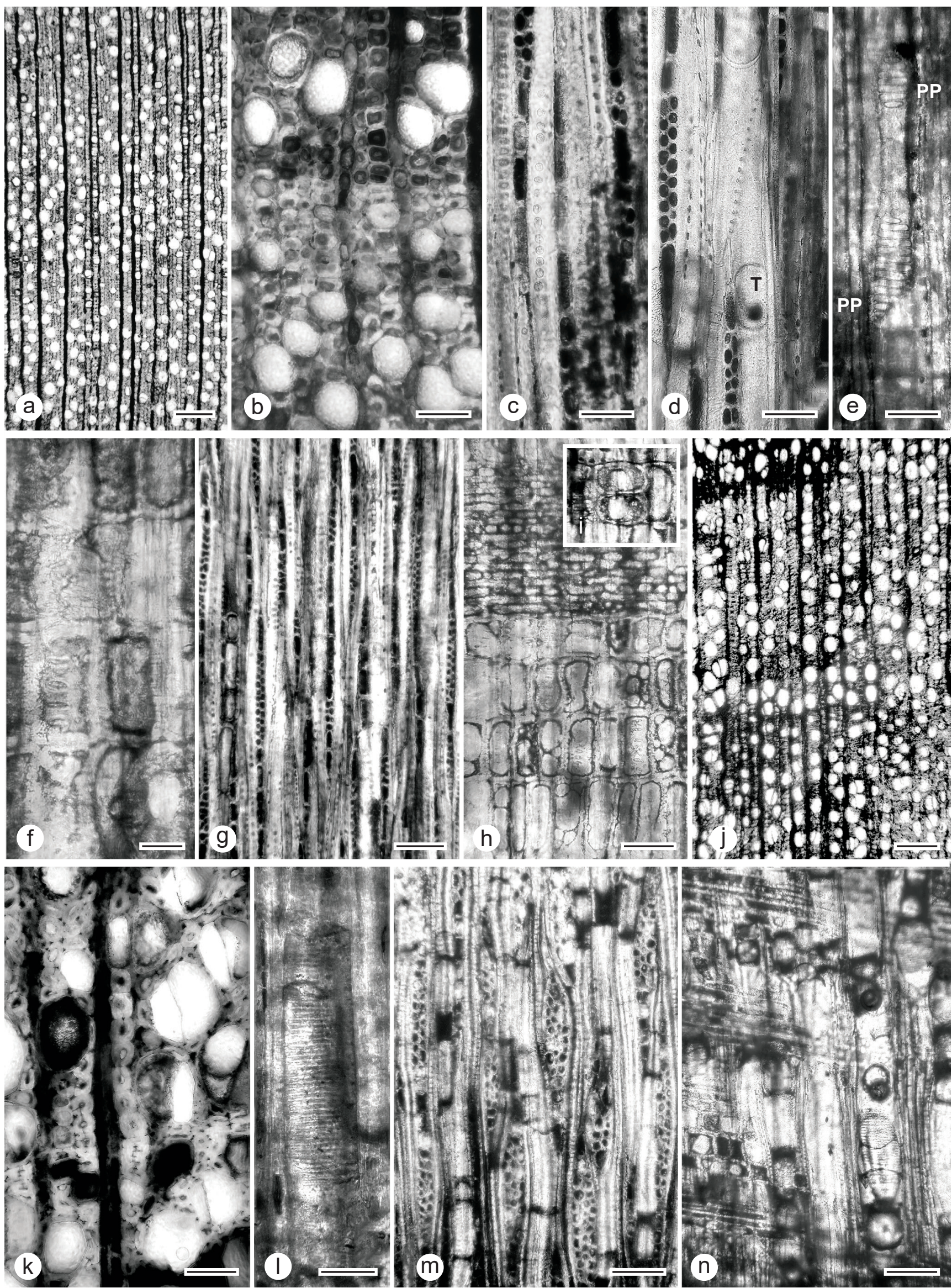

Text-fig. 7. Hamamelidoxylon crystalliferum sp. nov., UF 279-34464. a: Diffuse porous wood with exclusively solitary vessels, tending to be angular in outline, TS. b: Growth ring boundary, marked by radially narrowed fibers, latewood vessels narrower than earlywood vessels of the next ring, fibers thick-walled, no axial parenchyma visible, TS. c: Scalariform intervessel pits in narrow vessel (left), fibers with distinctly bordered pits, TLS. d: Scalariform perforation plate, tyloses (T) formation from marginal ray cell, TLS. e: Scalariform perforation plates with fewer than 15 bars (PP), RLS. f: Vessel-ray parenchyma pits with 
Table 2. Comparison of Hamamelidoxylon species. Arranged by age, oldest to youngest. GR = Growth ring boundaries, $\mathrm{I}=$ indistinct, $\mathrm{D}=$ distinct; $\mathrm{VTD}=$ vessel tangential diameter in $\mu \mathrm{m}$, standard deviation in parentheses when $\mathrm{known} ; \mathrm{V} / \mathrm{mm}^{2}=\mathrm{vessels} \mathrm{per} \mathrm{mm}^{2}$; Bars/PP = number of bars per perforation plate; $\mathbf{R W}=$ ray width in cell number; $\mathbf{C r y}=$ crystals, $\mathbf{R c h}=$ crystals in chambered square / upright cells, $\mathrm{I}=$ crystalliferous cells inflated; $\mathrm{K}=$ Cretaceous, Pal $=$ Paleocene, $\mathbf{E o}=$ Eocene, Mio = Miocene, $\mathrm{e}=\mathrm{early}, \mathrm{m}=\mathrm{middle}$, $\mathrm{I}$ = late; $\mathrm{OR}=$ Oregon, WA = Washington.

\begin{tabular}{|l|c|c|c|c|c|c|c|c|}
\hline \multicolumn{1}{|c|}{ Taxon (Reference) } & GR & VTD $(\boldsymbol{\mu m})$ & $\mathbf{V} / \mathbf{m m} \mathbf{2}$ & Bars/PP & RW & Cry & Age & Locality \\
\hline $\begin{array}{l}\text { Hamamelidoxylon crystalliferum } \\
\text { sp. nov. (UF 279-24555) (this paper) }\end{array}$ & $\mathrm{D} / \mathrm{I}$ & $47(6)$ & $122-149$ & $11-15$ & $1-3$ & Rch, I & 1 Eo & OR, USA \\
\hline $\begin{array}{l}\text { Hamamelidoxylon crystalliferum } \\
\text { sp. nov. (UF 279-34464) (this paper) }\end{array}$ & $\mathrm{D} / \mathrm{I}$ & $43(8)$ & $104-131$ & $11-15$ & $1-2(-3)$ & Rch, I & 1 Eo & OR, USA \\
\hline $\begin{array}{l}\text { Hamamelidoxylon cf. suzukii } \\
\text { (UF 279-34465) (this paper) }\end{array}$ & $\mathrm{D}$ & $58(11)$ & $85-117$ & $18-32$ & $1-2(-3)$ & $\mathrm{R}$ & 1 Eo & OR, USA \\
\hline H. obiraense (1) & $\mathrm{D}$ & 52 & $83-120$ & $22-56$ & $1(-2)$ & no & $1 \mathrm{~K}$ & Japan \\
\hline H. uniseriatum (2) & $\mathrm{D}$ & $58(13)$ & $72-133$ & $24-40$ & $1(-2)$ & no & $\mathrm{m}$ Eo & OR, USA \\
\hline cf. H. uniseriatum (3) & $\mathrm{D}$ & $55(11)$ & $50-82$ & $20-36$ & 1 & no & $\mathrm{m}$ Eo & OR, USA \\
\hline H. daphniphylloides (4) & $\mathrm{D}$ & 45 & $?$ & $30-58$ & $1-2(-3)$ & no & Eo & Germany \\
\hline H. renaultii (5, 6) & $\mathrm{D}$ & 36 & $119-200$ & 32 & $1(-2)$ & no & Mio, Pal/Eo & France, UK \\
\hline H. beckii (7) & $\mathrm{D} / \mathrm{I}$ & $54(7)$ & $77-94$ & $14-24$ & $1(-2)$ & $\mathrm{R}$ & $\mathrm{m}$ Mio & WA, USA \\
\hline H. suzukii (7) & $\mathrm{D}$ & $53(7)$ & $60-86$ & $16-27$ & $1-2$ & $\mathrm{R}$ & $\mathrm{m}$ Mio & WA, USA \\
\hline H. rhenanum (8) & $\mathrm{I}$ & $30-50 \mu \mathrm{m}$ & $?$ & $20-25$ & $1-2(-3)$ & no & Mio & Germany \\
\hline H. castellanense (9) & $\mathrm{I}$ & $40-60$ & $80-100$ & ca. $16-20$ & $1-2(-3)$ & Rch, I & Mio & France \\
\hline
\end{tabular}

1. Takahashi and Suzuki (2003), 2. Wheeler and Manchester (2002), 3. Wheeler and Manchester (2007), 4. Gottwald (1992), 5. Lignier (1907), 6. Crawley (2001), 7. Wheeler and Dillhoff (2009), 8. van der Burgh (1973), 9. Grambast-Fessard (1969)

chambered upright ray cells does not match any of the other species and indicates it is appropriate to create a new species.

Liquidambaroxylon and all Altingiaceae never possess crystals in chambered upright ray cells.

Co-occurring fruits/seeds. The fossil genus Fortunearites MANCHESTER, known from infructescence in the middle Eocene Clarno Nut Beds, Oregon, has a combination of characters found only in Fortunearia and Sinowilsonia (Manchester 1994, Manchester et al. 2009). It is possible that these two late Eocene wood samples might be related to the plant that produced Fortunearites. However, present-day Fortunearia wood has banded axial parenchyma, so is distinct from Sinowilsonia and these Post Hammer woods.

\section{Hamamelidoxylon cf. suzukii E.A.WHEELER et T.A.Dillhoff, 2009 Text-fig. $7 \mathrm{j}-\mathrm{n}$}

Materia l. UF 279-34465. Minimum estimated axis diameter $30 \mathrm{~cm}$.

Description. Growth rings boundaries distinct, marked by a few rows of radially narrow fibers, with latest latewood vessels narrower than the first earlywood vessels (Text-fig. 7j, k). Wood diffuse-porous.

Vessels predominantly solitary, angular in outline (Textfig. 7j, k), mean tangential diameter 58 (11), range 45-90 $\mu \mathrm{m}$; $85-117 / \mathrm{mm}^{2}$; perforations all scalariform, $18-41$ bars (Textfig. 71); vessel element lengths average 997 (146) $\mu \mathrm{m}$.
Fibers non-septate, thick walled; distinctly bordered pits on radial walls and tangential walls (Text-fig. $7 \mathrm{k}, \mathrm{m}, \mathrm{n}$ ).

Axial parenchyma rare, diffuse (Text-fig. 7k).

Rays 1-2(-3)-seriate (Text-fig. 7m), heterocellular (Text-fig. $7 \mathrm{~m}$ ); ray body composed of procumbent cells, with marginal rows of square cells, (Text-fig. $7 \mathrm{n}$ ).

Solitary crystals occasional in upright/square ray cells (Text-fig. 7n).

Comparisons with extant woods. The combination of features used to search InsideWood for this sample's affinities was similar to that used for the sample designated Hamamelidoxylon crystalliferum, except that we used crystals in upright/square ray parenchyma cells (137p) as a search criterion, not crystals in chambered upright ray parenchyma cells (140p). Results of this search returned Hamamelidaceae (Corylopsis, Mytilaria, Sinowilsonia), Altingiaceae (Liquidambar), and Cercidiphyllum. As we did for Cercidiphyllum, we used the work of Sakala and Privé-Gill (2004) on distinguishing between these families, and, in this case, conclude that this wood has affinities with the Hamamelidaceae.

Comparisons with fossil woods. Table 2 compares features of the Hamamelidoxylon species with relatively complete descriptions. Although there are differences in quantitative features (higher vessel frequency, rays more frequently 3 -seriate), we suggest this late Eocene wood is similar to Hamamelidoxylon suzukii (Wheeler and Dillhoff 2009) from the middle Miocene, Ginkgo Petrified Forest State Park, Washington, USA.

reduced borders and horizontally elongate, RLS. g: Rays 1-2-seriate, TLS. h: Upright cells approximately $4 \times$ higher than procumbent cells, RLS. i: Inflated chambered crystalliferous ray cell, RLS. Hamamelidoxylon cf. suzukii, UF 279-34465. j, k: Diffuse-porous wood with exclusively solitary vessels, angular in outline, thick-walled fibers, axial parenchyma not common, apotracheal diffuse, TS. 1 : Scalariform perforation plate with $>20$ bars, RLS. m: Rays mostly 2-3-seriate, TLS. n: Rays with procumbent body cells and square marginal cells. Scale bars: $200 \mu \mathrm{m}$ in a, j; $100 \mu \mathrm{m}$ in $\mathrm{g}, \mathrm{m}, \mathrm{n} ; \mathbf{5 0} \mu \mathrm{m}$ in b, c, d, e, g, h, I, k, l; $20 \mu \mathrm{m}$ in f. 

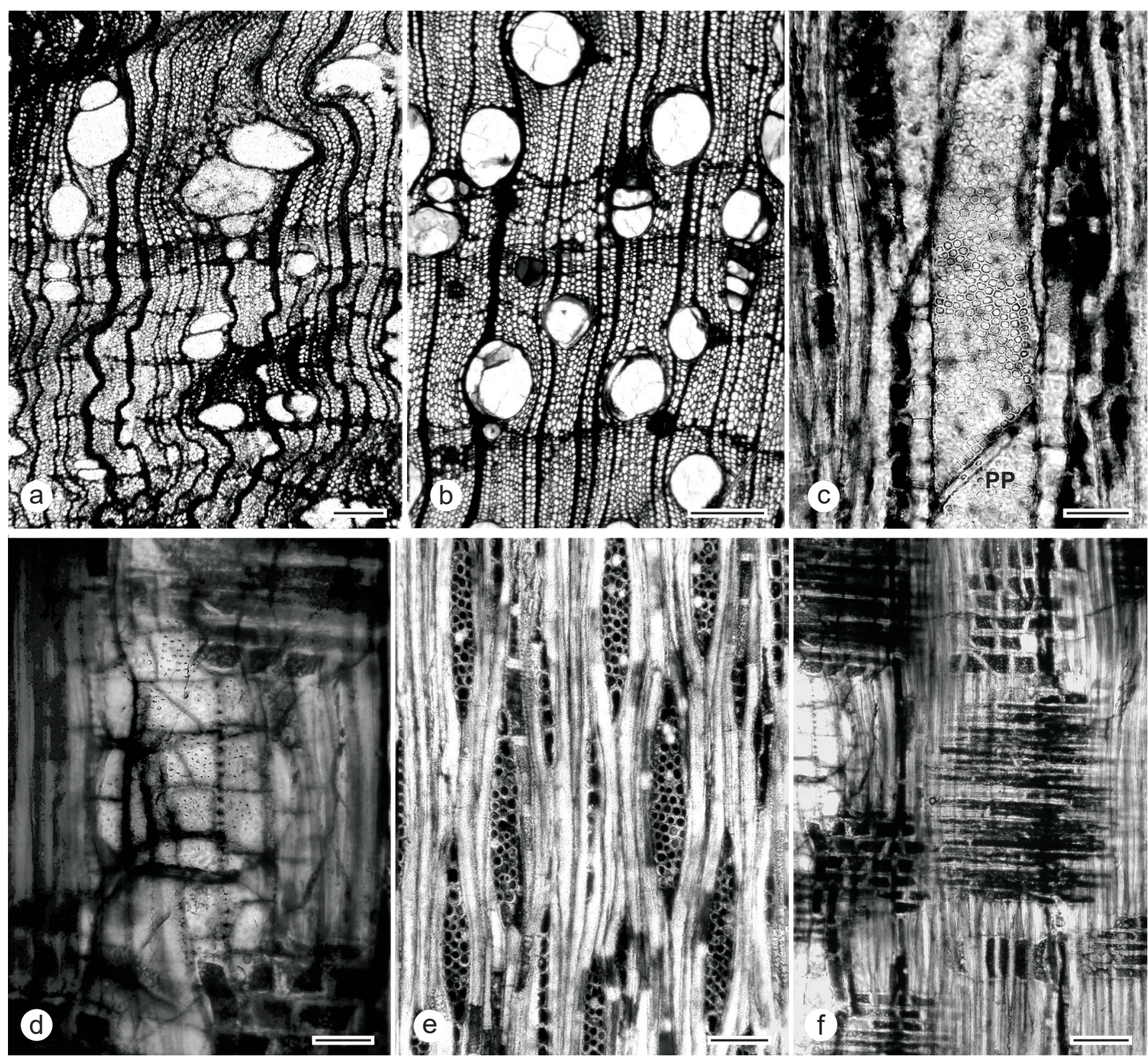

Text-fig. 8. Pterocaryoxylon sp., a-c, e: UF 279-85024; d, f: UF 279-24551. a, b: Wood semi-ring-porous, vessels solitary and in short radial multiples, axial parenchyma scanty vasicentric, marginal, and in narrow lines, TS. c: Crowded alternate intervessel pitting, simple perforation plate (PP), TLS. d: Vessel-axial parenchyma pitting similar to intervessel pitting, RLS. e: Rays mostly 1-3 cells wide, occasionally 4 cells, uniseriate rays probably mostly square to upright cells, TLS. f: Rays heterocellular, body cells procumbent. Scale bars: $200 \mu \mathrm{m}$ in a, b; $100 \mu \mathrm{m}$ in e, f; $50 \mu \mathrm{m}$ in $\mathrm{c} ; 20 \mu \mathrm{m}$ in $\mathrm{d}$.

Family Juglandaceae DC. ex Perleb, 1818 nom. cons.

Genus Pterocaryoxylon sensu Müller-Stoll and Mädel (1960)

\section{Pterocaryoxylon sp.}

Text-fig. 8a-f

Material. UF 279-24551 (minimum estimated diameter $11.8 \mathrm{~cm}$ ), UF 279-24557 (minimum estimated diameter $13 \mathrm{~cm}$ ), UF 279-85024.

Description. Growth rings present, marked by radially flattened fibers and differences in latewood and earlywood vessel diameters of successive growth rings (Text-fig. 8a, b). Semi-ring-porous.

Vessels solitary and in radial multiples of 2, average tangential diameter of earlywood 206 (28) $\mu \mathrm{m}$, range
124-294 $\mu \mathrm{m}$; perforations simple, intervessel pits alternate (Text-fig. 8c), ca. $7 \mu \mathrm{m}$; vessel-parenchyma pits similar to intervessel pits (Text-fig. 8d); vessel element lengths averages 460 (73)-486 (88) $\mu \mathrm{m}$; thin-walled tyloses occasional.

Fibers non-septate, thin-walled, pits not observed.

Axial parenchyma scanty paratracheal to vasicentric, marginal, and in tangential bands one to two cells wide throughout the growth ring, lines more closely spaced in the latewood than in the earlywood (Text-fig. 8a, b); strands usually of eight cells.

Rays 1-3(4)-seriate (Text-fig. 8e). Multiseriate rays heterocellular, with procumbent body cells and usually with 1-2 marginal rows of square to upright cells; uniseriate rays composed of mostly upright cells (Text-fig. 8f), total multiseriate ray height averages $382(91) \mu \mathrm{m}$, range 225$625 \mu \mathrm{m} .10-12 / \mathrm{mm}$. 
Table 3. Comparison of Pterocaryoxylon knowltonii and UF 279 Pterocaryoxylon sp. EW VTD = earlywood vessel tangential diameter in $\mu \mathrm{m}$; $\mathrm{LW}=$ latewood; IV = intervessel; VE = vessel element length.

\begin{tabular}{|l|c|c|}
\hline \multicolumn{1}{|c|}{ Feature } & Pterocaryoxylon knowltonii & UF 279 Pterocaryoxylon sp. \\
\hline EW VTD $(\mu \mathrm{m})$ & $160-215-310$ & $124-206-294$ \\
\hline LW vessel arrangement & Diagonal & Tending to diagonal \\
\hline IV pit size $(\boldsymbol{\mu m})$ & $10-12$ & ca. 7 \\
\hline VE length $(\mu \mathrm{m})$ & $460-850$ (range) & $460(73)-486(88)$ \\
\hline Ray width $(\mathrm{cell}$ number) & $1-3$ & $1-3(-4)$ \\
\hline Ray height $(\boldsymbol{\mu m})$ & $155-315($ range $)$ & $222-382-625$ \\
\hline
\end{tabular}

Crystals not observed. Storied structure absent.

Remarks. These juglandaceous woods were compressed and contorted, especially their earlywood. For measuring vessel diameters, we selected vessels that were oval to circular in outline and that we considered to be close to their original outline in the living tree.

Comparisons with extant woods.Affinities with Juglandaceae are indicated by the combination of semiring-porosity, vessels solitary and in short radial multiples, narrow continuous lines of axial parenchyma, medium-sized alternate intervessel pits, vessel-ray parenchyma pits similar in size to intervessel pits. Because these woods have exclusively simple perforations and lack crystals, they are most similar to Pterocarya KUnTH and the butternut group of Juglans L. (Asian species of Section Cardiocaryon, and the American $J$. cinerea L., traditionally placed in section Trachycaryon). Phylogenetic analyses confirm a close relationship between Pterocarya and Juglans (Stanford et al. 2000, Manos et al. 2007). Sometimes Pterocarya woods can be distinguished from the butternuts because latewood vessels in Pterocarya can be in a pronounced diagonal pattern (Müller-Stoll and Mädel 1960, Miller 1976, Wheeler et al. 1978). A difference between these Post Hammer woods and woods of extant Pterocarya and the Juglans butternut group is that rays in the recent woods typically are homocellular with all procumbent cells. However, some extant juglandaceous species have heterocellular rays (e.g., Juglans californica S.WATSON of section Rhysocaryon, BWCw 8695).

Comparisons with fossil woods. Because of the similarity of woods of Pterocarya and the butternut group of Juglans, Müller-Stoll and Mädel (1960) created the genus Pterocaryoxylon. One species is known from North America; Pterocaryoxylon knowltonii E.A.WHEELER, R.A.Scott et BArgh. (Wheeler et al. 1978) from the early middle Eocene of Yellowstone National Park, Wyoming. Table 3 compares this older species to the Post Hammer Pterocaryoxylon and shows the latter differ in having smaller intervessel pits and taller rays. Growth rings of the Post Pterocaryoxylon are narrower than those of the Yellowstone wood. When growth rings are narrow, latewood vessel arrangement patterns may not be obvious (IAWA Committee 1989). It is possible that if this Post wood had wider growth rings, a diagonal latewood vessel arrangement would have been observed. We are hesitant to create a new species based on differences in quantitative features and are choosing to refer to these Post Hammer woods as Pterocaryoxylon sp. The Yellowstone Pterocaryoxylon also has heterocellular rays. These western North America Pterocaryoxylon are the oldest known species of the genus. Pterocaryoxylon and Pterocarya have been reported from the Miocene-Pliocene of central and eastern Asia (e.g., Rajput and Khan 1982, Choi et al. 2010, Cheng et al. 2018), and Europe (e.g., MüllerStoll and Mädel 1960, Privé 1974, Dupéron 1988). MüllerStoll and Mädel (1960) cited another character of the type species of Pterocaryoxylon, not strictly a wood character, but useful to confirm affinity with the Pterocarya-JuglansCyclocarya group and distinguishing it from all other extant genera of the Juglandaceae: septate pith. The center of the stem is not known for these Eocene species.

The two juglandaceous woods of the nearby older middle Eocene Nut Beds, Oregon, differ: Clarnoxylon blanchardii Manchester et E.A.WHEeler (which has solid pith rather than septate) has prismatic crystals commonly occurring in enlarged ray parenchyma cells; Engelhardioxylon nutbedensis MANCHESTER has both simple and scalariform perforation plates and prismatic crystals in ray parenchyma (Wheeler and Manchester 2002).

Co-occurring fruits/seeds. The bi-winged fruits of Pterocarya have not been confirmed prior to the Oligocene. However, the extinct 4-winged genus Cruciptera known from the middle to late Eocene of Oregon (Manchester 1991), the early middle Eocene of Yellowstone (pers. obs.), and middle Eocene of Germany (Manchester et al. 1994), seems to have been rather common. We speculate that Cruciptera may have been produced on trees with wood similar to that of Pterocarya, and it may have corresponded to Pterocaryoxylon.

Family Malvaceae Juss., 1789 nom. cons.

\section{Genus Wataria K.Terada et Mits.Suzuki, 1998}

Wataria kvacekii sp. nov. Text-fig. 9a-h

Holotype. Here designated. UF 279-24546 (Textfig. $9 \mathrm{a}-\mathrm{h})$.

Plant Fossil Names Registry Number. PFN002682 (for new species).

Repository. Paleobotany Collections, Florida Museum of Natural History, Gainesville, Florida, USA.

E ty m o logy. Species name to honor Zlatko Kvaček, a kind man, who was and will continue to be an inspiration for those who study Tertiary floras.

Type 1 o cality. UF 279. About $3 \mathrm{~km}$ east of Post, Crook County, Oregon, USA. 

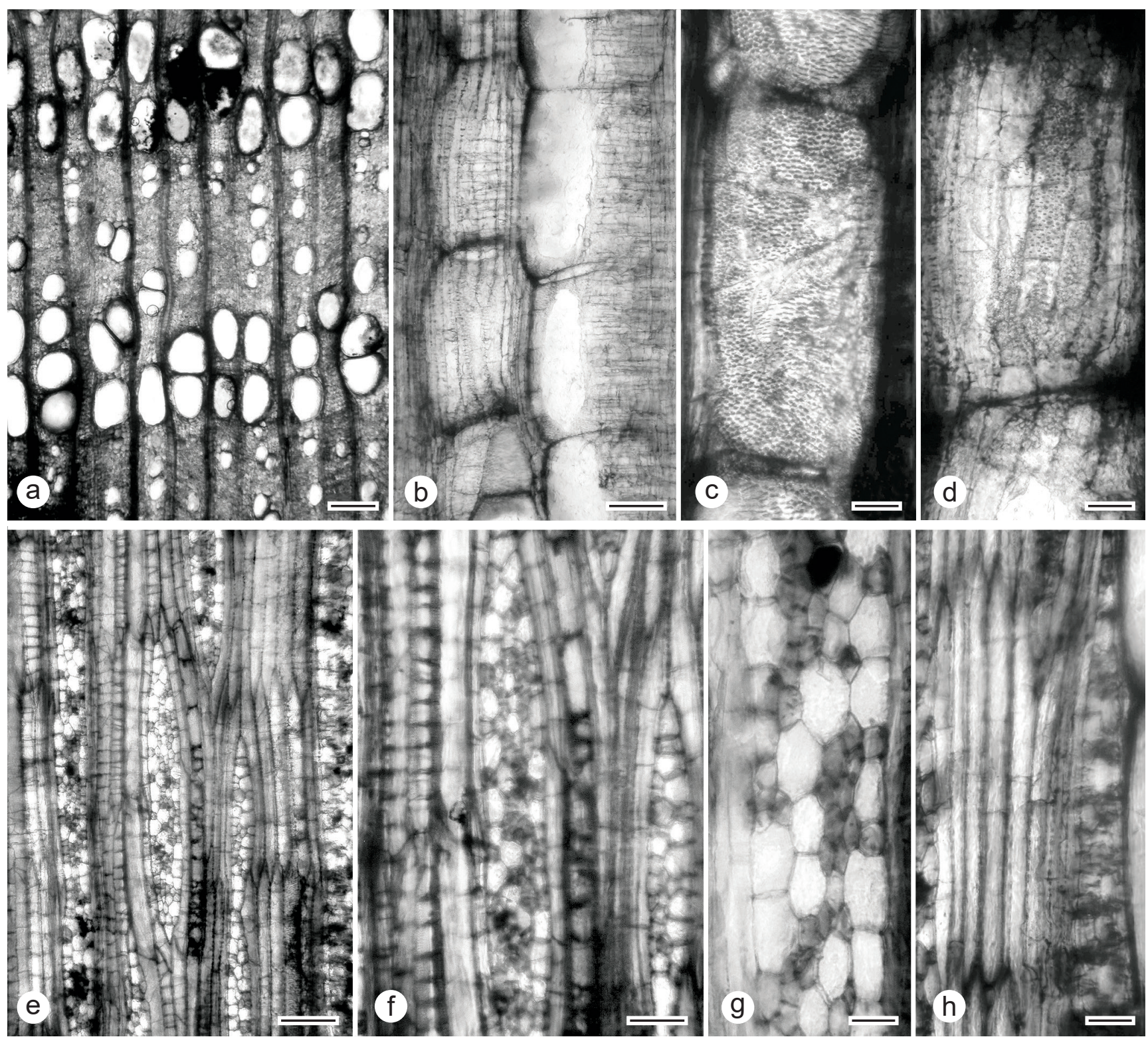

Text-fig. 9. Wataria kvacekii sp. nov., UF 279-24556. a: Wood ring-porous, earlywood with 2-3 rows of wide pores, vessels solitary and in radial multiples of 2, axial parenchyma scanty vasicentric and some apotracheal diffuse-in-aggregates, TS. b: Series of vessel elements with simple perforations, axial parenchyma strands adjacent to vessels, RLS. c: Alternate intervessel pitting, vessel element end walls horizontal, RLS. d: Vessel-axial parenchyma pitting similar to intervessel pitting, RLS. e, f: Rays with tile cells, storied axial parenchyma, some strands chambered crystalliferous, TLS. g: Detail of ray, TLS. h: Storied imperforate elements. Scale bars: $200 \mu \mathrm{m}$ in a; $100 \mu \mathrm{m}$ in b, e; $50 \mu \mathrm{m}$ in c, d, f, h; $20 \mu \mathrm{m}$ in g.

Type stratum and age. John Day Formation, Eocene.

D i a g n o s i s. Wood ring-porous. Earlywood zone with more than 1 row of earlywood vessels. Vessels solitary and in short radial multiples. Perforation plates exclusively simple. Intervessel pits alternate, small; vessel-ray parenchyma pits similar to intervessel pits. Vessel elements and imperforate elements regularly or irregularly storied. Axial parenchyma scanty paratracheal to vasicentric and diffuse-in-aggregates. Rays typically less than 10-seriate; heterocellular; commonly $>1 \mathrm{~mm}$ high. Tile cells present, Pterospermum-type.

Description. Growth rings present, marked by radially flattened fibers, and differences in diameters of latewood and earlywood vessels of subsequent rings (Text- fig. 9a). Wood distinctly ring-porous, earlywood pore zone usually 3 vessels deep.

Vessels predominantly solitary and in occasional radial multiples of 2 in both earlywood and latewood (Text-fig. 9a); average tangential diameter of earlywood vessels 143 (33) $\mu \mathrm{m}$; perforations simple (Text-fig. 9b); intervessel pits alternate (Text-fig. 9c), 3-5 $\mu \mathrm{m}$ in horizontal diameter; vessel-parenchyma pits similar to intervessel pits (Text-fig. 9d); vessel element length averages 346 (26), range 310-410 $\mu \mathrm{m}$; widely spaced thin-walled tyloses present; helical thickenings not observed.

Fibers thin to medium-thick-walled, storied, without distinctly bordered pits; non-septate, tending to be storied structure (Text-fig. 9e, h).

Axial parenchyma scanty paratracheal to vasicentric, (diffuse-) diffuse-in-aggregates, strands of 4-8 (Text- 
Table 4. Comparison of Wataria species and Triplochitioxylon. EW VTD = earlywood vessel tangential diameter in $\mu \mathrm{m}$; EW row $=$ number of rows of wide earlywood vessels; IVP = horizontal diameter of intervessel pits in $\mu \mathrm{m}$; VEL = vessel element lengths in $\mu \mathrm{m} ; \mathrm{RW}=$ width in cell number; $\mathbf{R} \mathbf{H t}=$ ray height in $\mu \mathrm{m} ;$ Cry $=$ Crystal location, $\mathbf{A P c}=$ chambered axial parenchyma, $\mathrm{R}=$ ray parenchyma; $\mathrm{Eo}=$ Eocene, $\mathrm{Ol}=$ Oligocene, Mio = Miocene, $\mathrm{e}=$ early, $\mathrm{m}=$ middle, $\mathrm{l}=$ late; $\mathrm{OR}=$ Oregon .

\begin{tabular}{|c|c|c|c|c|c|c|c|c|}
\hline Taxon (Reference) & EW VTD & EW row & IVP & VEL $(\mu \mathrm{m})$ & RW & R Ht $(\mu \mathrm{m})$ & Cry & Age, Country \\
\hline Wataria kvacekii sp. nov. (this paper) & 143 & $(1-) 2-3$ & $3-5$ & $310-346-410$ & $1-6$ & $320-1075-2600$ & $\mathrm{APc}$ & 1 Eo, OR, USA \\
\hline Wataria miocenica $(1,2)$ & $257-294$ & $(1-) 2-3$ & $2-4$ & $70-234-350$ & $1-10(-12)$ & $621,870,1280^{*}$ & APc, R & Mio, Japan \\
\hline Wataria miocenica (3) & 252 & $1-3$ & ? & $200-257-345$ & est. to 8 & $140-985-1900$ & $\mathrm{R}$ & Mio, Korea \\
\hline Wataria oligocenica (2) & 210 & $3-5$ & ca. 3 & $75-219-325$ & $1-10+$ & $200-688-1000$ & APc & Ol, Japan \\
\hline Wataria parvipora (2) & $150-181$ & $1-2(-3)$ & ca. 5 & $65-185-290$ & $(1-) 3-5(-7)$ & $550-803-1200$ & $\mathrm{R}$ & e Mio, Japan \\
\hline Wataria parvipora (3) & 181 & $1-2(-3)$ & ? & $125-178-250$ & $1-7$ & $120-558-900$ & $\mathrm{R}$ & e Mio, Korea \\
\hline Wataria yunnanica (4) & 270 & $1(-2-3)$ & ca. 3 & $144-280-569$ & $1-12$ & $193-873-2037$ & APc, R & m Mio, China \\
\hline Triplochitioxylon oregonense (5) & 185 & $\mathrm{n} / \mathrm{a}$ & $3-5$ & $400-440-600$ & $(1-) 4-6(-10)$ & $?-1267-2100$ & $\mathrm{R}$ & m Eo, OR, USA \\
\hline
\end{tabular}

1. Watari (1952), 2. Terada and Suzuki (1998), 3. Jeong et al. (2003), 4. Li et al. (2015), 5. Manchester (1979)

* mean ray heights

fig. 9a, b), also chambered with solitary prismatic crystals (Text-fig. 9e, f). Rays 1-6-seriate (Text-fig. 9e).

Multiseriate rays heterocellular with uniseriate rows of 1-3 cells; Pterospermum-type tile cells present; (Text-fig. 9f, g) some rays the same height as the vessel elements and axial parenchyma strands, most rays extending over multiple tiers of the storied parenchyma. Total multiseriate ray height averages 1,075 (634) $\mu \mathrm{m}, 320-2,600 \mu \mathrm{m}$. 5-8 mm.

Axial parenchyma and vessel elements storied (Textfig. 9e).

Comparisons with extant woods. Tile cells are unique to the Malvales. A search of the InsideWood database for the combination of tile cells (111p) and ringporosity ( $3 p$ ) only returned species of the present-day genera Grewia L. (Malvaceae/Grewioideae) and Reevesia LindL. (Malvaceae/Helicteroideae), and the fossil wood genus Wataria from the Oligocene - Miocene of Asia, whose species were originally assigned to Reevesia (Terada and Suzuki 1998).

Ring-porous species of Grewia and Reevesia differ from Wataria kvacekii because their latewood vessels are in clusters.

Comparisons with fossil woods. Rodríguez-Reyes et al. (2014) reviewed the characteristics of fossil malvaceous woods and noted only two genera with distinctly ring-porous species: Reevesia and Wataria. Selmeier (2000b) described semi-ring-porous Grewioxylon with a transition from earlywood to latewood that is gradual. This Post Hammer wood generally conforms to the genus Wataria K.Terada et Mits.Suzuki (Terada and Suzuki 1998), diagnosed as having distinctly ring-porous woods, earlywood vessels mostly solitary with latewood vessels mostly solitary, not in clusters; perforation plates simple; alternate intervessel pitting; helical thickenings absent; storied axial parenchyma, heterocellular multiseriate rays with tile cells. To date, four species of Wataria have been described $W$. miocenica K.Terada et Mits.Suzuki, $W$. oligocenica K.Terada et Mits. SuzuKi, $W$. parvipora K.Terada et Mits.SuzuKi, and $W$. yunnanica YAN-JIE Li et OsKOLSKI (Tab. 4). Species have been distinguished based on number of rows of wide earlywood vessels, latewood vessel grouping, and crystal occurrence (e.g., Li et al. 2015). There also are differences in quantitative features (earlywood vessel diameter, vessel element length, axial parenchyma strand length, ray width and height). Table 4 indicates that this Wataria kvacekii's combination of the aforementioned features differs from previously described Wataria species and so consider it a new species. Axial parenchyma is not as easy to see in the Post Wataria wood as it is in the Asian species, but as best we can determine its distribution is similar to other species.

Two types of malvaceous woods were reported from the nearby middle Eocene Nut Beds flora, Clarno Formation, Oregon, both are semi-ring-porous to diffuse-porous, without a well-defined earlywood pore zone (Manchester and Miller 1978, Manchester 1979, 1980, Wheeler and Manchester 2002). Chattawaya paliforme MANCHESTER also differs because it lacks storied structure and its rays are wider (to 14-seriate). Although not distinctly ringporous, Triplochitioxylon oregonensis MANCHESTER shares many features with this Post Hammer wood: storied structure, intervessel pit size, vessel-ray parenchyma pit type, ray heights, crystals in chambered axial parenchyma. Terada and Suzuki (1998) commented on the similarities between Triplochitioxylon MANCHESTER and Wataria. Triplochitioxylon has longer vessel elements; averages of $440-487 \mu \mathrm{m}$ vs. average of $346 \mu \mathrm{m}$ with a maximum of 410 $\mu \mathrm{m}$ for Wataria kvacekii. This difference likely is related to most measurements for the Post Wataria being of the barrel-shaped earlywood vessel elements. Wide earlywood vessel elements are shorter than the narrow latewood vessels (e.g., Süss 1967, Kitin et al. 1999); it's been suggested that the widening of earlywood vessel elements in ring-porous woods results in their shortening (Chalk and Chattaway 1935). It is tempting to hypothesize that Wataria kvacekii belongs to the same lineage as Triplochitioxylon and that the differences in porosity between them are associated with the increasing seasonality in the transition from the middle Eocene to the late Eocene.

Co-occurring fruits/seeds. Malvaceae recognized from fruits from the Teater Road locality include Craigia W.W.Sm. et W.E.Evans and the extinct genus Florissantia KNOwLt. (Manchester 1992: figs 34, 


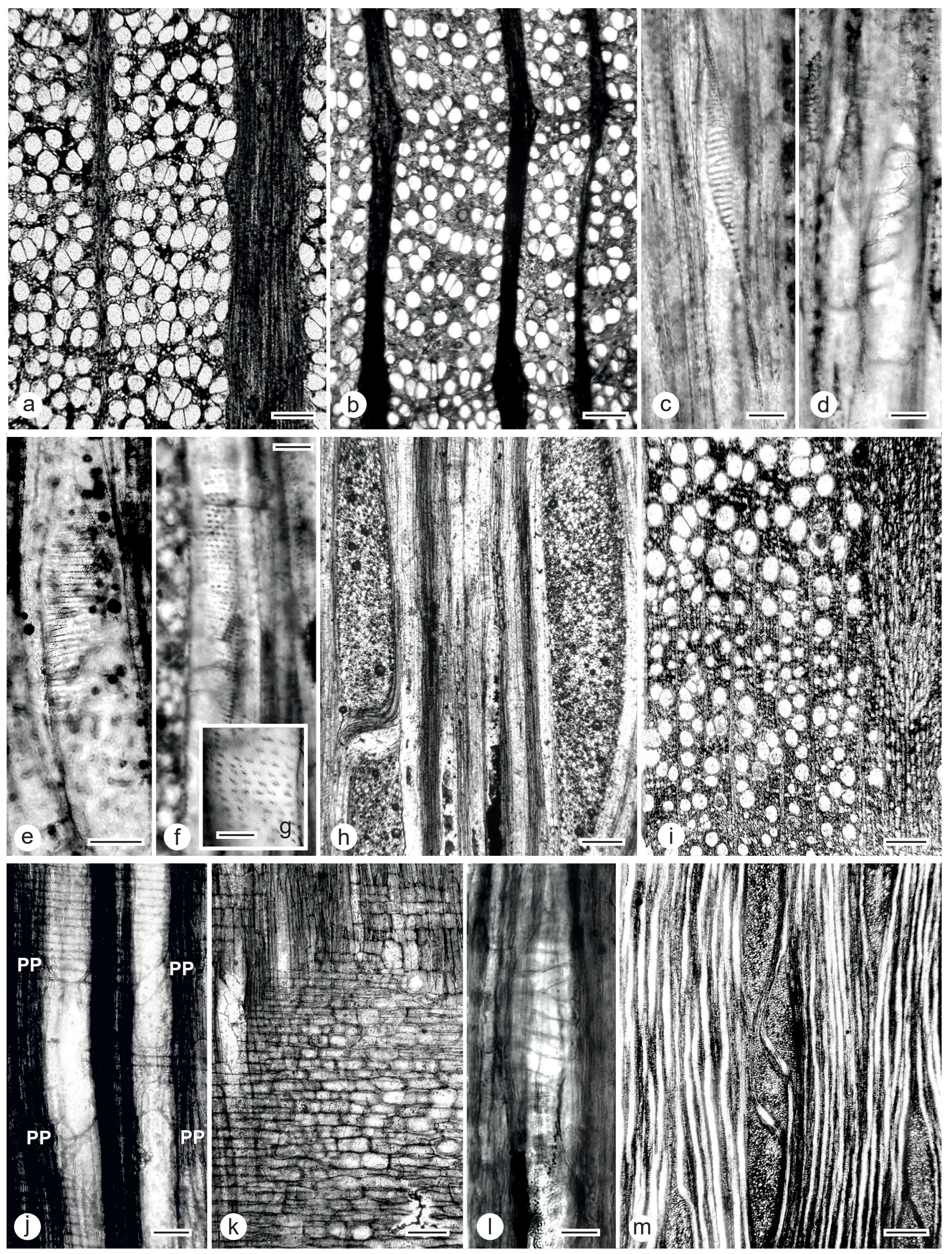

Text-fig. 10. Platanoxylon cf. haydenii, a, e, h: UF 279-34470; b, c, d, f g: UF 279-34469. a, b: Diffuse porous wood with vessels solitary and in small multiples, which are mostly tangential or oblique, diffuse and diffuse-in-aggregates axial parenchyma., TS. c-e: Scalariform perforation plates. f, g: Opposite intervessel pits, TLS. h: Two size classes of rays, TLS. Platanus sp., UF 27924552. i: Predominantly solitary vessels, diffuse and diffuse-in-aggregates parenchyma, growth ring boundary distinct, noded rays, TS. j: Simple perforation plates (PP), RLS. k: Body of ray with procumbent ray cells, RLS. I: Scalariform perforation plate, RLS. m: Rays of two sizes, wide rays >10-seriate, TLS. Scale bars: $200 \mu \mathrm{m}$ in a, b, h, i, m; $100 \mu \mathrm{m}$ in j, k: $50 \mu \mathrm{m}$ in c, d, e, f, l. 
35, 37-40). Extant Craigia wood is distinguished from the fossil wood treated here by its helically thickened vessel elements, wider rays ( $>10$-seriate), and lack of storied structure (Manchester et al. 2006). Fossils of flowers and fruits with the distinctive persistent calyx of Florissantia occur in eastern Asia (Manchester 1999: fig. 7B) as well as at various localities in North America. Pollen from the anthers of Florissantia flowers is similar to that of Tilia L. and Craigia (Manchester 1992, Kvaček et al. 2005). Based on circumstantial evidence of co-occurrence, it is possible that Wataria/Triplochitioxylon trees may have borne flowers corresponding to the genus Florissantia.

\section{Family Platanaceae T.LestiB., 1826 nom. cons.}

\section{Genus Platanoxylon ANDr., 1952 emend. by Süss and Müller-Stoll (1977) \\ Platanoxylon cf. haydenii (FELIX) SüsS et Müll.-Stoll, 1977 \\ Text-fig. 10a-h}

M a teri a 1. UF279-34469; UF 279-34470, minimum estimated axis diameter $30 \mathrm{~cm}$.

Description. Growth rings present, marked by slightly noded rays and 1-2 rows of radially narrow fibers. Wood diffuse-porous.

Vessels solitary and in short multiples, some tangentially arranged (Text-fig. 10a, b); average tangential diameter 76 (11) $\mu \mathrm{m}$, range 59-96 $\mu \mathrm{m}$; average $45 / \mathrm{mm}^{2}$. Perforation plates exclusively scalariform, generally with fewer than 20 bars (Text-fig. 10c, d); intervessel pits opposite (Textfig. 10f, g), vessel-ray parenchyma pits not observed.

Fibers non-septate, pits not observed.

Axial parenchyma diffuse-in-aggregates, in interrupted short uniseriate lines (Text-fig. 10a, b, f).

Rays of two distinct sizes, larger rays often $>20$ cells wide (Text-fig. 10a, b, h), composed of procumbent cells, sometimes with 1-2 marginal rows of square cells; multiseriate ray height averages $3.05 \mathrm{~mm}$, range 1.1$5.53 \mathrm{~mm}$.

R e m a r k s . Although vessel-ray parenchyma pits were not observed in these samples, their other characteristics indicate they are Platanoxylon (narrow numerous vessels, some in tangential multiples (Text-fig. 10a, b); scalariform perforation plates (Text-fig. 10c, d, e); opposite intervessel pits (Text-fig. 10f, g); diffuse-in-aggregates parenchyma; tall and wide rays composed mostly of procumbent cells (Text-fig. 10h). The characteristics that distinguish them from other woods with wide rays (e.g., Fagus and Euptelea) were detailed by Scott and Wheeler (1982) and discussed earlier with reference to Fagus dodgei. Platanoid woods are common in the Paleogene of western North America. Woods similar to Platanoxylon haydenii are common in the older Clarno Formation, with multiple samples occurring at both the Nut Beds (Wheeler and Manchester 2002) and Hancock Canyon (Wheeler and Manchester 2014). These Post Hammer woods with their exclusively scalariform perforation plates are similar to other Eocene platanoid woods and differ from present-day Platanus woods that have both simple and scalariform perforation plates.

\section{Genus Platanus L., 1753 \\ Platanus sp. \\ Text-fig. $10 \mathrm{i}-\mathrm{m}$}

Material. UF 279-24552, minimum estimated axis diameter $30 \mathrm{~cm}$.

Description. Growth rings present, marked by noded rays, rows of radially narrow latewood fibers, and differences between vessel diameters between latest latewood and earliest earlywood. Wood diffuse-porous (Text-fig. 10i).

Vessels predominantly solitary, occasionally in oblique or tangential multiples; average tangential diameter 58 (9) $\mu \mathrm{m}$, range $42-77 \mu \mathrm{m} ; 82-102$ vessels $/ \mathrm{mm}^{2}$. Perforation plates predominantly simple (Text-fig. 10j), rare scalariform perforation plates with fewer than 15 bars (Text-fig. 101); scalariform intervessel pits observed at ends of vessel elements, vessel-ray parenchyma pits horizontally elongated. Vessel element lengths average 499 (100) $\mu \mathrm{m}$, range 260-740 $\mu \mathrm{m}$.

Fibers non-septate, thick-walled.

Axial parenchyma diffuse, diffuse-in-aggregates, and in interrupted short uniseriate lines (Text-fig. 10i).

Rays of two distinct sizes, narrow rays 1-3-seriate (Textfig. $10 \mathrm{~m}$ ), larger rays to 24 cells wide and $6.6 \mathrm{~mm}$ high; heterocellular, body of procumbent cells with 1-4 marginal rows of square to upright cells. In radial section, some ray cells appear enlarged and possibly crystalliferous (Textfig. 10k).

Remarks. We place this wood in Platanus, rather than Platanoxylon, because it has predominantly simple perforation plates like the extant genus, in contrast with woods of Platanoxylon/Plataninium, which have exclusively or predominantly scalariform perforation plates. The horizontally elongate vessel-ray parenchyma pits are not typical of extant Platanus but occasionally occur in the Vietnamese species P. kerrii GAGneP. The occurrence of multiple types of Platanaceae woods agrees with the leaf and fruit record.

Coeval megafossils of Platanaceae from the late Eocene of Oregon include dispersed fruits with the distinctive basal tuff of hairs diagnostic of extant Platanus from the Teater Road locality (Manchester and Lott, pers. obs.). Also present in the region during the late Eocene are leaves of the extinct genera Macginitiea J.A.WoLFE et WEHR (and associated fruits of Macginicarpa which lack dispersal hairs, late Eocene of Gray Butte and middle Eocene Clarno Formation sites), Platameliphyllum N.Maslova (Clarno Formation sites; Huegele et al. 2022) Platanites E.Forbes (John Day Gulch locality of the Clarno Formation) as well as extant Platanus leaves (Clarno Formation sites).

Family Sapindaceae Juss., 1789 nom. cons.

$$
\text { Genus Acer L., } 1753
$$

\section{Acer Post Hammer sp. 1}

Text-fig. $11 \mathrm{a}-\mathrm{e}$

Material. UF 279-34456 (minimum estimated diameter $12.5 \mathrm{~cm})$. 

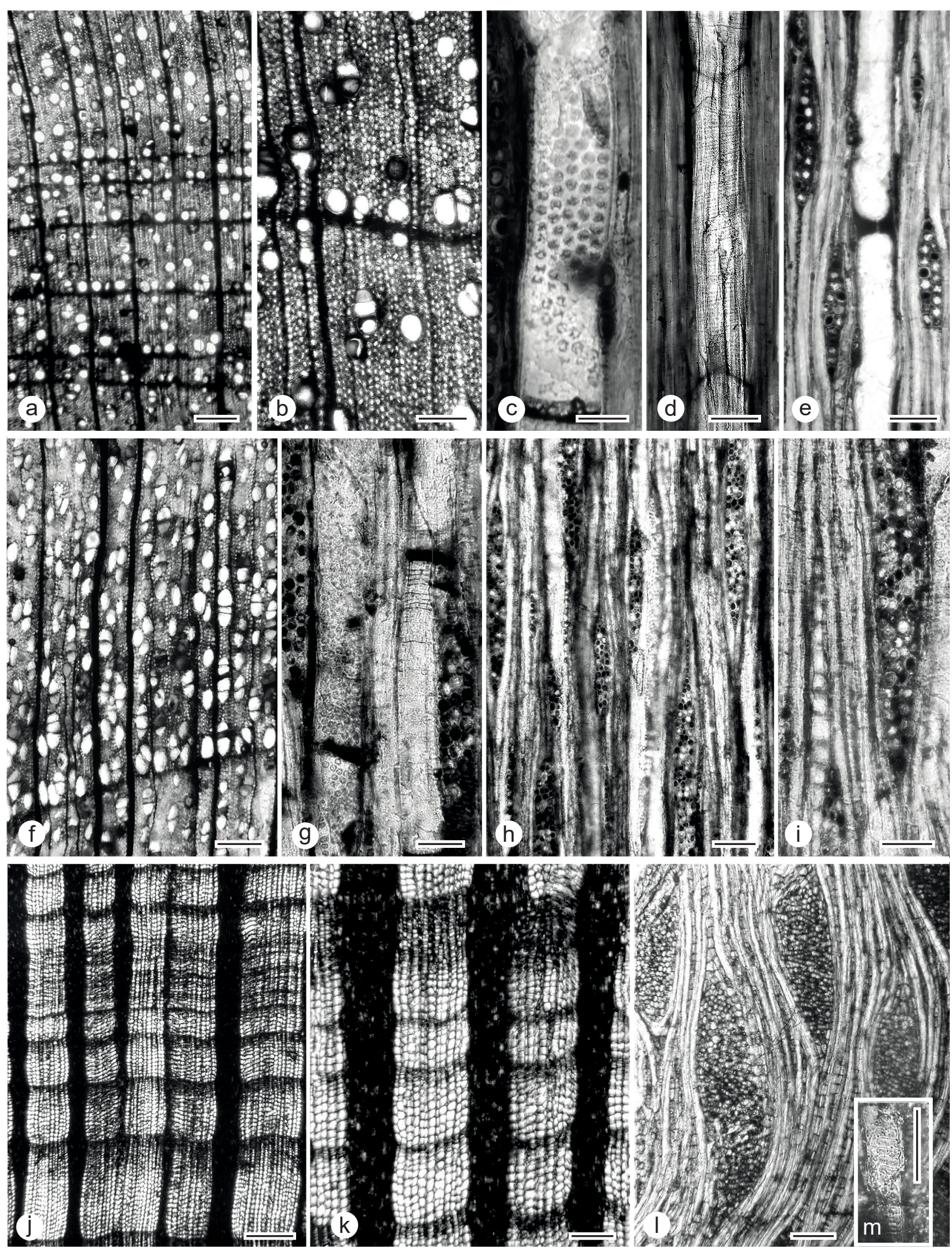

Text-fig. 11. Acer Post Hammer species 1, UF 279-34456. a, b: Diffuse-porous wood with distinct growth rings, marked by marginal parenchyma, vessels solitary and in short radial multiples, TS. c: Crowded alternate intervessel pits, TLS. d: Simple perforation plates, helical thickenings in vessel elements, TLS. e: Rays 2-3-seriate, gum deposit in vessel element, TLS. Acer Post Hammer species 2. UF 279-34466. f: Diffuse-porous wood with distinct growth rings, marked by marginal parenchyma, vessels solitary and in short radial multiples, TS. g: Alternate intervessel pits, helical thickenings in vessel elements, TLS. h: Rays 1-4(-5)-seriate, TLS. i: Crystalliferous strand, multiseriate ray, TLS. Trochodendron beckii, UF 279-24558. j, k: Distinct growth rings, abrupt transition from earlywood to latewood, vesselless, wide rays noded at growth ring boundaries, TS. I: Rays of two distinct sizes, uniseriate and multiseriates $>10$-seriate, TLS. m. Scalariform intertracheary pits. RLS. Scale bars: $500 \mu \mathrm{m}$ in j; $200 \mu \mathrm{m}$ in a, f, k, l; $100 \mu \mathrm{m}$ in b, h; $50 \mu \mathrm{m}$ in c, d, e, g, i, m. 
Description. Growth rings distinct, marked by radially flattened fibers. Diffuse-porous (Text-fig. 11a, b). Vessels solitary (57\%) and in radial multiples of 2(-3); average tangential diameters $40(\mathrm{SD}=10)$, range 24-63 $\mu \mathrm{m}$; vessel frequency $50-56 / \mathrm{mm}^{2}$; perforations exclusively simple (Text-fig. 11d); gum deposits appear accumulated at ends of vessel elements (Text-fig. 11e); intervessel pits crowded alternate, mostly polygonal in outline with included apertures (Text-fig. 11c), small to medium; vesselray parenchyma pits similar in size and shape to intervessel pits; helical thickenings present along entire length of the vessel element (Text-fig. 11d).

Fibers non-septate, walls thin to medium, pitting not observed.

Axial parenchyma marginal. (Text-fig. 11a, b).

Rays 1-3(-4)-seriate (Text-fig. 11e). Homocellular, composed of procumbent cells; multiseriate ray height averages 238 (69) $\mu \mathrm{m} ; 8-10 / \mathrm{mm}$.

Storied structure absent; crystals not observed.

\section{Acer Post Hammer sp. 2}

Text-fig. $11 \mathrm{f}-\mathrm{i}$

Materia l. UF 279-34466.

Description. Growth rings distinct, marked by radially flattened fibers. Diffuse-porous (Text-fig. 11f). Vessels solitary (48\%) and in radial multiples of 2-4; average tangential diameter 55 (11), range 39-73 $\mu \mathrm{m}$; vessel frequency $64-78 / \mathrm{mm}^{2}$; perforations simple; intervessel pits crowded alternate (Text-fig. 11g), rounded to polygonal in outline with included apertures, $8-10 \mu \mathrm{m}$; vessel-ray parenchyma pits similar in size and shape to intervessel pits; helical thickenings present along entire length of the vessel element; (Text-fig. 11g) vessel element lengths 275-495 $\mu \mathrm{m}$; mean $390 \mu \mathrm{m}(\mathrm{n}=12)$; tyloses absent. Fibers non-septate, walls of thin to medium thickness, pitting not observed. Axial parenchyma marginal (Text-fig. 11f), apparently diffuse; strands of chambered crystalliferous cells with more than 16 chambers perstrand(Text-fig. 11i); one crystal perchamber. Rays 1-4(-5)-seriate (Text-fig. 11h). Multiseriate rays homocellular, composed of procumbent cells; multiseriate ray height averages 512 (206) $\mu \mathrm{m}$, range 175-850 $\mu \mathrm{m}$; $5-7 / \mathrm{mm}$. Chambered crystalliferous cells, occasional, more than 16 chambers per strand; one crystal per chamber. Storied structure absent.

Comparisons with extant woods. Woods of Acer are relatively easy to identify to genus because of their distinctive combination of features: diffuse-porosity (5p), vessels solitary and in short radial multiples (6a 7a 8a 9a 10a 11a), exclusively simple perforation plates (13p 14a), alternate intervessel pits that are neither minute nor large (22p 24a 27a), vessel-ray parenchyma pits similar in size and shape to the intervessel pits (30p), spiral thickenings throughout the vessel elements (36p 37p), vessels not wide or few (42a 43a 46a), non-septate fibers with simple to minutely bordered pits (61p 65a 66p), non-storied homocellular rays that are not exclusively uniseriate or $>10$-seriate (96a 99a $104 \mathrm{p} 118 \mathrm{a}$ ), axial parenchyma not abundant and marginal parenchyma present (77a 79a 80a 83a 86a 89p) and in some species crystals in chambered axial parenchyma cells (e.g., Brazier and Franklin 1961, Panshin and DeZeeuw 1980).
Dipteronia OLIV. wood differs from Acer wood in that helical thickenings are uncommon and faint in the narrower vessel elements; it also differs from these Post maple woods as its rays are wider (to 6-seriate) and commonly $>1 \mathrm{~mm}$ high (T. Itoh, personal communication).

Today there are $\sim 125$ Acer species (Mabberley 2017). It is not easy to identify an isolated piece of maple wood of unknown geographic origin to a species or section. In Ogata's (1967) monograph of the genus, he suggested ray shape, ray width in cell number, and crystal occurrence are useful for distinguishing sections in Acer. Based on these features we recognize two species of Acer in the UF 279 assemblage.

Comparisons with fossil woods. The oldest known wood with features unique to Acer occurs in the middle Eocene Clarno Nut Beds (Wheeler and Manchester 2002). Takahashi and Suzuki (1988) reviewed the record for fossil Acer woods. More recently, fossil Acer woods have been reported from Asia (Jeong et al. 2009) and Turkey (Akkemik et al. 2016, 2018, Bayam et al. 2018). Table 5 compares their features; this table only includes reports for stem wood with reasonably complete anatomical descriptions and images. The Turkish Miocene woods are distinct from all other Acer fossil woods because of their markedly higher vessel frequency. Acer PH sp. 1, which lacks crystals, is similar to A. minokamoensis E.K.JEONG, KyUng.Kim et Mits.Suzuki in vessel diameter and ray size, but its description only notes that the vessels are numerous. Thus, it is not clear whether or not they are similar in vessel frequency. Acer PH sp. 2 differs from other crystal-bearing fossil Acer woods in vessel frequency and ray height. We are hesitant to provide diagnoses that rely heavily on differences in quantitative features for distinguishing species.

Co-occurring fruits/seeds or leaves. Wolfe and Tanai (1987) described seven species of Acer based on leaf and fruit remains from the Teater Road locality, which they referred to as Sheep Rock Creek. Dipteronia fruits are also recognized there (McClain and Manchester 2001).

Family Trochodendraceae EICHLER, 1865 nom. cons.

Genus Trochodendron Siebold et Zucc., 1839

\section{Trochodendron beckii (Hergert et H.K.PhInNEY) R.A.SCOTT et E.A.WHEELER, 1982 Text-fig. $11 \mathrm{j}-\mathrm{m}$}

Material. UF279-24558 (estimated minimum diameter of stem $15 \mathrm{~cm}$ ), USNM 326709 (holotype, estimated minimum diameter $18 \mathrm{~cm}$ ).

$\mathrm{D}$ e s c r i p t i o $\mathrm{n}$. Growth rings distinct, marked by noded rays and abrupt transition in radial diameters of latewood tracheids to the subsequent ring's earlywood tracheids. Vessels absent. Transition from earlywood to latewood abrupt. Tangential diameter of earlywood tracheids 29 (7), 15-51 $\mu \mathrm{m}$; tangential diameter of latewood tracheids 26 (5) $\mu \mathrm{m}, 17-42$; scalariform intertracheary pitting observed on radial walls; axial parenchyma rare, occasional isolated cells; rays of two distinct sizes: uniseriates and multiseriates up to 15 cells wide; uniseriates numerous, composed 
Table 5. Comparison of Acer species. Arranged by age, oldest to youngest. VTD = vessel tangential diameter in $\mu \mathrm{m}$, mean (standard deviation) or minimum-average-maximum; $\mathrm{V} / \mathrm{mm}^{2}=$ vessels per $\mathrm{mm}^{2}$, range or average as a single number; $\mathrm{RW}=$ ray width in cell number; MsRH = multiseriate ray height in $\mu \mathrm{m}$, mean (standard deviation) or minimum-average-maximum; Cry $=$ crystals present in long chambered strands; Eo = Eocene, Mio = Miocene, $\mathrm{e}=$ early, $\mathrm{m}=$ middle, $\mathrm{l}=$ late; $\mathrm{OR}=$ Oregon, WA = Washington.

\begin{tabular}{|l|c|c|c|c|c|c|c|}
\hline \multicolumn{1}{|c|}{ Taxon $($ reference) } & VTD $(\boldsymbol{\mu m})$ & $\mathbf{V} / \mathbf{m m} \mathbf{2}$ & $\mathbf{R W}$ & MsRH $(\boldsymbol{\mu m})$ & Cry & Age & Country \\
\hline Acer integrifolioxylon (3) & $48(5)-50(7)$ & $88-97$ & $1-3(-4)$ & $297(137)-546(159)$ & Yes & m Eo & OR, USA \\
\hline Acer Post Hammer sp. 1 (this paper) & $24-40-63$ & $50-56$ & $1-3(-4)$ & $238(69)$ & No & 1 Eo & OR, USA \\
\hline Acer Post Hammer sp. 2 (this paper) & $39-55-73$ & $64-78$ & $1-4(-5)$ & $512(206)$ & Yes & 1 Eo & OR, USA \\
\hline \multirow{2}{*}{ A. momijiyamense (2, 5) } & $20-75($ range) & $20-70$ & $1-4(-5)$ & $50-600(-750) *$ & Rare & Ol & Japan \\
\cline { 2 - 8 } & $24-50-79$ & numerous & $1-4$ & $47-500-932$ & No & e Mio & Korea \\
\hline A. cf. amoenum (1) & up to $75 \mu \mathrm{m}$ & $?$ & $1-6(-9)$ & up to 1200 & Yes & e Mio & Japan \\
\hline Acer spp. (7) & 37 & 132 & $1-5$ & 214 & No & e Mio & Turkey \\
\hline Acer spp (6) & 55 & 206 & $1-5$ & 220 & No & e Mio & Turkey \\
\hline A. minokamoensis (5) & $24-43-55$ & numerous & $1-3$ & $79-290-505$ & No & e Mio & Korea \\
\hline A. pohangensis (5) & $24-39-55$ & numerous & $1-4$ & $32-600-1185$ & No & e Mio & Korea \\
\hline A. watarianum (2) & $30-90($ range) & $15-35$ & $1-5(-6)$ & $70-460($ range) & Yes & e Mio & Japan \\
\hline A. beckianum (4) & $31-60-82$ & $23-35$ & $1-3$ & $237(65)$ & Yes & m Mio & WA, USA \\
\hline A. berkhoffii (4) & $35-65-90$ & $17-24$ & $1-3$ & $365(135)$ & No & m Mio & WA, USA \\
\hline A. olearyii (4) & $30-59-80$ & $52-71$ & $1-7$ & $437(239)$ & No & m Mio & WA, USA \\
\hline A. puratanum (4) & $30-53-72$ & $18-26$ & $1-4(-5)$ & $230(60)$ & Yes & m Mio & WA, USA \\
\hline
\end{tabular}

1. Watari (1952), 2.Takahashi and Suzuki (1988), 3.Wheeler and Manchester (2002), 4.Wheeler and Dillhoff (2008), 5. Jeong et al. (2009), 6. Bayam et al. (2018), 7. Akkemik et al. (2016)

* 50-600 reported as range, with $750 \mu \mathrm{m}$ given as outlier.

exclusively of upright cells; central cells of multiseriate rays procumbent, with up to 10 marginal rows of upright cells, heights of multiseriate portions of the rays $0.7-1.56 \mathrm{~mm}$.

Note: We did not measure total ray height including the uniseriate margins because it was difficult to be sure of where the uniseriate margins ended.

Remarks. Vesselless woods are rare among angiosperms, and this specimen with its wide heterocellular rays and scalariform bordered pits has features of Trochodendraceae (Bailey and Nast 1945, Hergert and Phinney 1954). This specimen from the Post Hammer locality (UF 279) further documents the occurrence of Trochodendron wood in the Eocene of Oregon (Scott and Wheeler 1982). This species was previously recognized from the Miocene of Oregon (Hergert and Phinney 1954) from the same formation where fossil trochodendraceous infructescences and leaves have been recognized (Manchester et al. 2018). There are differences in the quantitative features (tracheid diameters, ray width) between the woods from these separate occurrences, but we don't consider them to be great enough to treat them as different species. Although the two extant genera of this family, Trochodendron and Tetracentron, are confined to eastern Asia, the family is well represented in the Cenozoic of western North America and known from leaves and fruits of both modern and extinct genera ranging from Paleocene to Miocene (Manchester et al. 2018, Manchester et al. 2021).

\section{Conclusions}

The wood assemblage from the late Eocene Post Hammer locality is smaller and less diverse than the middle Eocene Clarno Nut Beds wood assemblage. It includes woods with anatomy similar to extant genera: Pistacia (Anacardiaceae); Celtis (Cannabaceae), Cercidiphyllum (Cercidiphyllaceae), Fagus, Quercus of the red oak group (Fagaceae), Acer (Sapindaceae), Ulmus (Ulmaceae; Wheeler and Manchester 2007), and Trochodendron (Trochodendraceae).

To the best of our knowledge, the Pistacia, Celtis, and Trochodendron woods are the oldest occurrences of woods with characteristics unique to these genera. There is also a permineralized palm stem (UF 279-24547) from the same site. Angiosperm woods that can be identified to family but have a combination of features found in more than one extant genus of that family are Lithocarpoxylon, resembling Lithocarpus, Notholithocarpus, and the evergreen Quercus species (Fagaceae); Hamamelidoxylon (Hamamelidaceae); and Pterocaryoxylon, with features shared with Juglans (butternut group) and Pterocarya (Juglandaceae). Two genera are likely extinct because they can be identified to family but have a combination of features that does not conform to a modern genus: Wataria (Malvaceae), which also occurs in Japan, and Platanoxylon (Platanaceae), one of the most commonly occurring fossil woods in the Paleogene of the Northern Hemisphere. Study of this wood assemblage is an example of how studying coeval fruit and seed assemblages, leaf compressions, and woods provides a better understanding of the vegetation (Tab. 6).

These taxa are consistent with warm temperate possibly to subtropical vegetation. Differences between the Post Hammer assemblage and the Clarno Nut Bed assemblage document changes in vegetation and functional traits as would be expected as a result of the middle to late Eocene climatic change, increased seasonality and decreased mean annual temperature. All Post Hammer woods have distinct growth ring boundaries, whereas one-third of the Nut Beds have indistinct growth ring boundaries (Wheeler and 
Table 6. Taxonomic composition of the Post Hammer locality.

\begin{tabular}{|c|c|c|}
\hline Family & Wood taxa & Reproductive structures $^{2}$ \\
\hline Taxaceae & & Diploporus torreyoides seed \\
\hline Conifer & Indet. wood & \\
\hline Palmae & Indet. stem & Sabal seed \\
\hline Trochodendraceae & $\begin{array}{l}\text { Trochodendron beckii (HERGERT et H.K.PHINNEY) R.A.SCOTt et } \\
\text { E.A.WHEELER }\end{array}$ & \\
\hline \multirow[t]{2}{*}{ Platanaceae } & Platanoxylon haydenii (Felix) Süss et MüLl.-SToll & \\
\hline & Platanus sp. & \\
\hline Cercidiphyllaceae & Cercidiphyllum alalongum R.A.SCOTT et E.A.WHEELER & \\
\hline \multirow[t]{2}{*}{ Hamamelidaceae } & Hamamelidoxylon crystalliferum sp. nov. & \\
\hline & H. suzukii E.A.WHEELER et T.A.DilLHOFF & \\
\hline Betulaceae & & Alnus sp. infructescence \\
\hline \multirow[t]{4}{*}{ Fagaceae } & Fagus dodgeii sp. nov. & Fagus sp. nut \\
\hline & Quercus sp. & Quercus sp. nut \\
\hline & Lithocarpoxylon ashwillii sp. nov. & \\
\hline & Lithocarpoxylon sp. & \\
\hline \multirow[t]{2}{*}{ Juglandaceae } & Pterocaryoxylon sp. & \\
\hline & & Carya sp. nut \\
\hline Malvaceae & Wataria kvacekii sp. nov. & \\
\hline Anacardiaceae & Pistacia terrazasae sp. nov. & Indet. fruit similar to Pistacia \\
\hline Cannabaceae & Celtis popsii sp. nov. & \\
\hline \multirow[t]{2}{*}{ Ulmaceae } & Ulmus danielii E.A.WHEELER et MANCHESTER ${ }^{1}$ & \\
\hline & Ulmus woodii E.A.WHEELER et MANCHESTER & \\
\hline Sapindaceae & Acer, 2 spp. & \\
\hline Alangiaceae & & Alangium sp. fruit \\
\hline Davidiaceae & & Davidia fruit \\
\hline Mastixiaceae & & $\begin{array}{l}\text { Tectocarya sp. (misidentified as Mastixicarpum by Manchester } \\
\text { 2006) fruit }\end{array}$ \\
\hline
\end{tabular}

${ }^{1}$ presented by Wheeler and Manchester 2007

${ }^{2}$ presented in Manchester and McIntosh 2006

Manchester 2002). Moreover, two of the Post Hammer woods are distinctly ring-porous, a trait not seen in any of the Nut Beds woods; ring-porosity is correlated with the deciduous habit and distinct seasonality.

As research continues, we will compare this assemblage with other wood localities in the region. The Dietz locality (UF 278), situated a few km east of the Hammer locality, has also yielded well preserved woods in association with silicified fruits and seeds. Although we have encountered some of the same woods at UF 278 (Platanaceae, Ulmaceae), there are differences, including the presence of Magnoliaceae, Araliaceae, and more conifers.

\section{Acknowledgments}

We thank the N.C. State Libraries, Raleigh, N.C., for their continued support of the InsideWood web site, especially Carolyn Argentati, Adam Constabularis, and Shirley Rodgers; and Terry Lott, University of Florida, Gainesville, for helping with formatting and checking references, and help with fossil names registration; Pieter Baas and Jakub Sakala for their tactful and constructive reviews of the manuscript. Dewey Dietz provided guidance in the field. Dr. Jim Wood (Post, Oregon) kindly provided access to collect fossil plants from his Aspen Valley Ranch.

\section{References}

Abundiz-Bonilla, L. A. M., Baraja-Morales, J., Tenorio-Lezama, P. (2004): Anatomía de Maderas de México. Árboles y Arbustos del Matorral Xerófilo de Tehuacán, Puebla [Trees and shrubs of the xerophilous scrub of Tehuacán, Puebla]. - Publicaciones Especiales del Instituo de Biología, Universidad Nacional Autónoma de México, 19: 1-97. (in Spanish)

Akkemik, Ü., Arslan, M., Poole, I., Tosun, S., Köse, N., Kilic, N. K., Aydin, A. (2016): Silicified woods from two previously undescribed early Miocene forest sites near Seben, northwest Turkey. - Review of Palaeobotany and Palynology, 235: 31-51.

https://doi.org/10.1016/j.revpalbo.2016.09.012

Akkemik, Ü., Atıcı, G., Poole, I., Çobankaya, M. (2018): Three new silicified woods from a newly discovered earliest Miocene forest site in the Haymana Basin (Ankara, Turkey). - Review of Palaeobotany and Palynology, 254: 49-64.

https://doi.org/10.1016/j.revpalbo.2018.04.012

AL-Saghir, M. G. (2010): Phylogenetic analysis of the genus Pistacia L. (Anacardiaceae) based on morphological data. - Asian Journal of Plant Sciences, 9(1): 28-35. https://doi.org/10.3923/ajps.2010.28.35 
AL-Saghir, M. G. (2012): Taxonomic revision of the genus Pistacia L. (Anacardiaceae). - American Journal of Plant Sciences, 3: 12-32. https://doi.org/10.4236/ajps.2012.31002

Bailey, I. W., Nast, C. G. (1945): Morphology and relationships of Trochodendron and Tetracentron, I. Stem, root, and leaf. - Journal of the Arnold Arboretum, 26(2): 143-154. https://doi.org/10.5962/p.185529

Bande, M. B., Prakash, U. (1984): Occurrence of Evodia, Amoora, and Sonneratia from the Palaeogene of India. - In: Sharma, A. K., Mitra, G. C., Banerjee, M. (eds), Symposium on evolutionary botany and biostratigraphy (1979: Calcutta, India) (A. K. Ghosh commemoration volume / Current trends in life sciences, vol. 10). Today and Tomorrow's Printers \& Publishers, New Delhi, pp. 97-114.

Bayam, N. N. A., Akkemik, Ü., Poole, I., Akarsu, F. (2018): Further contributions to the early Miocene forest vegetation of the Galatian Volcanic Province, Turkey. - Palaeontologica Electronica, 21(3): 40 (42 pp.). https://doi.org/10.26879/816

Boura, A., De Franceschi, D. (2007): Is porous wood structure exclusive of deciduous trees? - Comptes Rendus Palevol, 6: 385-391. https://doi.org/10.1016/j.crpv.2007.09.009

Brazier, J. D., Franklin, G. L. (1961): Identification of hardwoods. A microscope key. - Forest Products Research Bulletin, 46: 1-96.

Brett, D. W. (1956): LXXXII. - Fossil wood of Cercidiphyllum Sieb. \& Zucc. from the London Clay. - Annals and Magazine of Natural History, Ser. 12, 9(105): 657-665. https://doi.org/10.1080/00222935608655873

Brown, R. W. (1935): Miocene leaves, fruits and seeds from Idaho, Oregon, and Washington. - Journal of Paleontology, 9: 572-587, pls 67-69.

van der Burgh, J. (1973): Hölzer der niederrheinischen Braunkohlenformation, 2. Hölzer der Braunkohlengruben "Maria Theresia" zu Herzogenrath, "Zukunft West" zu Eschweiler und "Victor" (Zülpich Mitte) zu Zülpich. Nebst einer systematisch-anatomischen Bearbeitung der Gattung Pinus L. - Review of Palaeobotany and Palynology, 15: 73-275. https://doi.org/10.1016/0034-6667(73)90001-8

Carlquist, S. (2001): Comparative wood anatomy. $2^{\text {nd }}$ ed. Springer, Berlin, 448 pp. https://doi.org/10.1007/978-3-662-04578-7

Chalk, L, Chattaway, M. M. (1935): Factors affecting dimensional variations of vessel elements. - Tropical Woods, 40: 19-26.

Chaney, R. W. (1948): The ancient forests of Oregon. - Oregon State System of Higher Education, Condon Lecture, Eugene, Oregon, 56 pp.

Cheng, Y.-M., Mehrotra, R. C., Jin, Y.-G., Yang, W., Li, C.-S. (2012): A new species of Pistacioxylon (Anacardiaceae) from the Miocene of Yunnan, China. - IAWA Journal, 33(2): 197-204. https://doi.org/10.1163/22941932-90000089

Cheng, Y.-M., Wang, Y.-F., Liu, F.-X., Jin, Y.-G., Mehrotra, R. C., Jiang, X.-M., Li, C.-S. (2018): The Neogene wood flora of Yuanmou, Yunnan, southwest China. - IAWA Journal, 39(4): 427-474.

https://doi.org/10.1163/22941932-20170214

Choi, S.-K., Kim, K., Jeong, K., Terada, K., Suzuki, M., Uematsu, H. (2010): Fossil woods from the Yamagutu Prefecture. - IAWA Journal, 31(1): 95-117. https://doi.org/10.1163/22941932-90000009

Collinson, M. E. (1986): Use of modern generic names for plant fossils. - In: Spicer, R. A., Thomas, B. A. (eds), Systematic and taxonomic approaches in palaeobotany (Systematic Association Special Volume 31). Oxford University Press, Clarendon Press, Oxford, New York, pp. 91-104.

Crane, P. R., Stockey, R. A. (1985): Growth and reproductive biology of Joffrea speirsii gen. et sp. nov., a Cercidiphyllum-like plant from the Late Paleocene of Alberta, Canada. - Canadian Journal of Botany, 63: 340-364. https://doi.org/10.1139/b85-041

Crawley, M. (1989): Dicotyledonous wood from the lower Tertiary of Britain. - Palaeontology, 32: 597-622.

Crawley, M. (2001): Angiosperm woods from British Lower Cretaceous and Palaeogene deposits. - Special Papers in Palaeontology, 66: 1-100.

Denk, T., Grimm, G. W. (2009): The biogeographic history of beech trees. - Review of Palaeobotany and Palynology, 158: 83-100.

https://doi.org/10.1016/j.revpalbo.2009.08.007

Dillhoff, R. M., Dillhoff, T. A., Dunn, R. E., Myers, J. A., Stromberg, C. A. E. (2009): Cenozoic paleobotany of the John Day Basin, central Oregon. - In: O'Connor, J. E., Dorsey, R. J., Madin, I. P. (eds), Volcanoes to Vineyards. Geologic Field Trips through the Dynamic Landscape of the Pacific Northwest (Geological Society of America Field Guide no. 15). Geological Society of America, Boulder, pp. 135-164. https://doi.org/10.1130/978-0-8137-0015-1

Dupéron, J. (1973): Oleoxylon aginnense n. gen. n. sp., Pistacioxylon muticoides n. gen. n. sp., bois fossiles tertiaires de la région de Grateloup. - Bulletin de la Société botanique de France, 120: 311-330.

https://doi.org/10.1080/00378941.1973.10839173

Dupéron, J. (1988): Les bois fossiles de Juglandaceae: inventaire et révision. - Review of Palaeobotany and Palynology, 53: 251-282. https://doi.org/10.1016/0034-6667(88)90035-8

Fahn, A., Werker, E., Baas, P. (1986): Wood anatomy and identification of trees and shrubs from Israel and adjacent regions. - The Israel Academy of Sciences and Humanities, Jerusalem, $221 \mathrm{pp}$.

Golovneva, L. B., Alekseev, P. I. (2017): Taxonomy and morphological diversity of infructescence Jenkinsella co-occurred with Trochodendroides leaves in the Cretaceous and Paleogene. - Paleobotanika [Paleobotany], 8: 92-121. https://doi.org/10.31111/palaeobotany/2017.8.92

Gottwald, H. (1992): Hölzer aus marinen Sanden des oberen Eozän von Helmstedt (Niedersachsen). - Palaeontographica, Abt. B, 225: 27-103, 20 pls.

Gottwald, H. (2004): Neue taxonomische Untersuchungen an 205 tertiären Hölzern und 2 verkieselten Rindenresten aus der Südlichen Frankenalb and deren Randgebieten - 
mit Aussagen über Herkunft und Flora, Klima und Alter. - Dokumente naturae, 153: 1-93.

Grambast-Fessard, N. (1969): Contribution a l'étude des flores Tertiaires des regions provencales et alpines: V. Deux bois de dicotyledones a caracteres primitifs du Miocene superieur de Castellane. - Naturalia monspeliensia, Série Botanique, 20: 105-118.

Gregory, M., Poole, I., Wheeler, E. A. (2009): Fossil dicot wood names. - IAWA Journal, Supplement 6: 1-230.

Guo, W.-Y., Yang, J., Gromyko, D., Ablaev, A. G., Wang, Q., Li, C.-S. (2010): First record of Cercidiphylloxylon (Cercidiphyllaceae) from the Palaeocene of Fushun, NE China. - Journal of Systematics and Evolution, 48(4): 302-308.

https://doi.org/10.1111/j.1759-6831.2010.00083.x

Hanson, C. B. (1996): Stratigraphy and vertebrate faunas of the Bridgerian-Duchesnean Clarno Formation, North-Central Oregon. - In: Prothero, D. R., Emry, R. J. (eds), The terrestrial Eocene-Oligocene transition in North America. Cambridge University Press, Cambridge, pp. 206-239.

https://doi.org/10.1017/CBO9780511665431.012

Hergert, H., Phinney, H. K. (1954): Trochodendroxylon beckii gen. et sp. nov. from the Tertiary of Oregon. - Bulletin of the Torrey Botanical Club, 81: 118-122. https://doi.org/10.2307/2481846

Huegele, I. B., H. Zhu, Zhao, B.L., Wang Y.-F., S.R. (2022): Trans-Beringial distribution of Platimeliphyllum (Platanaceae) in the Eocene of eastern Asia and western North America. - International Journal of Plant Sciences, 183(2): 139-153. [published online December 14, 2021] https://doi.org/10.1086/717692

Hoadley, B. (1990): Identifying wood. Accurate results with simple tools. - Taunton Press, Newtown, Connecticut, 233 pp.

IAWA Committee (1989): IAWA list of microscopic features for hardwood identification with an appendix on non-anatomical features. - IAWA Bulletin, s.n., 10(3): 219-232. https://doi.org/10.1163/22941932-90000496

Ilic, J. (1991): CSIRO Atlas of Hardwoods. - Springer-Verlag, Berlin, 525 pp.

InsideWood (2004-onwards): Published on the Internet. http://insidewood.lib.ncsu.edu [accessed 2016 - 2021]

Jeong, K., Kim, K., Kim, J.H., Suzuki, M. (2003): Comparison of Korean and Japanese Tertiary fossil wood floras with special references to the genus Wataria. - Geosciences Journal, 7(2): 157-161.

https://doi.org/10.1007/BF02910219

Jeong, K., Kim, K., Suzuki, M., Kim, J. W. (2009): Fossil woods from the lower coal-bearing formation of the Janggi Group (Early Miocene) in the Pohang Basin, Korea. - Review of Palaeobotany and Palynology, 153: 124-138.

https://doi.org/10.1016/j.revpalbo.2008.07.006

Kitin, P., Funada, R., Sano, Y., Beeckman, H., Ohtani, J. (1999): Variations in the lengths of fusiform cambial cells and vessel elements in Kalopanax pictus. - Annals of Botany, 84: 621-632.

https://doi.org/10.1006/anbo.1999.0957

Kvaček, Z., Manchester, S. R., Akhmetiev, M. A. (2005): Review of the fossil history of Craigia (Malvaceae s.l.) in the northern hemisphere based on fruits and co-occurring foliage. -In: Akhmetiev, M. A., Herman, A. B. (eds), Modern Problems of Palaeofloristics, Palaeophytogeography, and Phytostratigraphy. GEOS, Moscow, pp. 114-140.

Li, Y.-Y., Oskolski, A. A., Jacques, F. M. B., Zhou, Z.-K. (2015): New middle Miocene fossil wood of Wataria (Malvaceae) from southwest China. - IAWA Journal, 36(3): 345-357.

https://doi.org/10.1163/22941932-20150105

Lignier, O. (1907): Vegetaux fossiles de Normandie 4. Bois divers. - Memoires de la Société Linnéenne de Normandie, Sér. 1, 22: 237-333.

Lynch, A. H., Gasson, P. E. (2010): Index Xylariorum - Edition 4. Royal Botanic Gardens, Kew [on-line source].

Mabberley, D. J. (2017): Mabberley’s Plant-book: A Portable Dictionary of Plants, Their Classification and Uses. $4^{\text {th }}$ ed. - Cambridge University Press, Cambridge, 1102 pp. https://doi.org/10.1017/9781316335581

Manchester, S. R. (1979): Triplochitioxylon (Sterculiaceae): a new genus of wood from the Eocene of Oregon and its bearing on xylem evolution in the extant genus Triplochiton. - American Journal of Botany, 66: 699-708. https://doi.org/10.1002/j.1537-2197.1979.tb06274.x

Manchester, S. R. (1980): Chattawaya (Sterculiaceae): a new genus of wood from the Eocene of Oregon and its implications for xylem evolution of the extant genus Pterospermum. - American Journal of Botany, 67: 59-67. https://doi.org/10.1002/j.1537-2197.1980.tb07624.x

Manchester, S. R. (1991): Cruciptera: A new juglandaceous winged fruit from the Eocene and Oligocene of western North America. - Systematic Botany, 16(4): 715-725. https://doi.org/10.2307/2418873

Manchester, S. R. (1992): Flowers, fruits, and pollen of Florissantia, an extinct malvalean genus from the Eocene and Oligocene of western North America. - American Journal of Botany, 79(9): 996-1008. https://doi.org/10.1002/j.1537-2197.1992.tb13689.x

Manchester, S. R. (1994): Fruits and seeds of the middle Eocene Nut Beds Flora, Clarno Formation, Oregon. - Palaeontographica Americana, 58: 1-205.

Manchester, S. R. (1999): Biogeographical relationships of North American Tertiary floras. - Annals of the Missouri Botanical Garden, 86: 472-522. https://doi.org/10.2307/2666183

Manchester, S. R., Chen, Z., Zhou, Z. (2006): Wood anatomy of Craigia (Malvales) from southeastern Yunnan, China. - IAWA Journal, 27: 129-136. https://doi.org/10.1163/22941932-90000142

Manchester, S. R., Chen, Z.-D., Lu, A.-M., Uemura, K. (2009): Eastern Asian endemic seed plant genera and their paleogeographic history throughout the Northern Hemisphere. Journal of Systematics and Evolution, 47(1): 1-42. https://doi.org/10.1111/j.1759-6831.2009.00001.x

Manchester, S. R., Collinson, M.E., Goth, K. (1994): Fruits of the Juglandaceae from the Eocene of Messel, Germany, and implications for early Tertiary phytogeographic exchange between Europe and western North America. International Journal of Plant Sciences, 155(3): 388-394. https://doi.org/10.1086/297176 
Manchester, S. R., Dillhoff, R. M. (2004): Fagus (Fagaceae) fruits, foliage, and pollen from the Middle Eocene of Pacific Northwestern North America. - Canadian Journal of Botany, 82: 1509-1517. https://doi.org/10.1139/b04-112

Manchester, S. R., Kvaček, Z., Judd, W. S. (2021): Morphology, anatomy, phylogenetics and distribution of fossil and extant Trochodendraceae in the Northern Hemisphere. - Botanical Journal of the Linnean Society, 195(3): 467-484.

https://doi.org/10.1093/botlinnean/boaa046

Manchester, S. R., McIntosh, W. C. (2007): Late Eocene silicified fruits and seeds from the John Day Formation near Post, Oregon. - PaleoBios, 27(1): 7-17.

Manchester, S. R., Miller, R. B. (1978): Tile cells and their occurrence in malvalean fossil woods. - IAWA Bulletin, 1978(2-3): 103-111.

Manchester, S. R., Pigg, K. B., DeVore, M. L. (2018): Trochodendraceous fruits and foliage in the Miocene of western North America. - Fossil Imprint, 74: 45-54. https://doi.org/10.2478/if-2018-0004

Manos, P. S., Cannon, C. H., Oh, S.-H. (2008): Phylogenetic relationships and taxonomic status of the paleoendemic Fagaceae of western North America: recognition of a new genus, Notholithcarpus. - Madroño, 55(3): 181-190. https://doi.org/10.3120/0024-9637-55.3.181

Manos, P. S., Soltis, P. S., Solti, D. E., Manchester, S. R., Bell, C. D., Dilcher, D. L., Stone, D. E. (2007): Phylogeny of extant and fossil Juglandaceae inferred from the integration of molecular and morphological data sets. Systematic Botany, 56(3): 412-430. https://doi.org/10.1080/10635150701408523

McClain, A. M., Manchester, S. R. (2001): Dipteronia (Sapindaceae) from the Tertiary of North America and Asia and implications for the phytogeographic history of the Aceroideae. - American Journal of Botany, 88: 1316-1325. https://doi.org/10.2307/3558343

Meyer, H. W., Manchester, S. R. (1997): The Oligocene Bridge Creek Flora of the John Day Formation, Oregon. - University of California Publications in Geological Sciences, 141: 1-195, 75 pls.

Miller, R. B. (1976): Wood anatomy and identification of species of Juglans. - Botanical Gazette, 137: 368-377. https://doi.org/10.1086/336886

Müller-Stoll, W. R., Mädel, E. (1957): Über tertiäre Eichenhölzer aus dem pannonischen Becken. - Senckenbergiana Lethaea, 38: 121-168.

Müller-Stoll, W. R., Mädel, E. (1960): Juglandaceen-Hölzer aus dem ungarischen Tertiär des pannonischen Becken. - Senckenbergiana Lethaea, 41: 255-295.

Ogata, K. (1967): A systematic study of the genus Acer. Bulletin Tokyo University Forestry, 63: 89-206.

Ogata, K., Fujii, T., Abe, H., Baas, P. (2008): Identification of the Timbers of Southeast Asia and the Western Pacific. - Kaiseisha Press, Otsu, 400 pp. https://doi.org/10.1515/HF.2008.132

Panshin, A. J., DeZeeuw, C. (1980): Textbook of Wood Technology. $4^{\text {th }}$ ed. - McGraw-Hill, New York, $722 \mathrm{pp}$.

Parfitt, D. E., Baldenes, M. L. (1997): Phylogeny of the genus Pistacia as determined by the chloroplast genome. -
Proceedings of the National Academy of Sciences, 94: 7987-7992.

https://doi.org/10.1073/pnas.94.15.7987

Pearson, H. L. P. (1987): Megafossil plants from Suffolk, a review of the pre-Pleistocene records. - Transactions of the Suffolk Naturalists' Society, 23: 56-63.

Petrescu, L. (1978): Studiul lemnelor fosile din Oligocenul din nord-vestul Transilvaniei [Study of fossil wood from the Oligocene of northwest Transylvania]. - Institut Geologie şi Geofizica, Mémorii 27: 113-184, 74 pls. (in Romanian)

Prakash, U., Březinová, D., Bůžek, Č. (1971): Fossil woods from the Doupovské Hory and České Středohoří Mountains in northern Bohemia. - Palaeontographica, Abt. B, 133: $103-128$.

Privé, C. (1974): Pterocaryoxylon subpannonicum n. sp., bois fossile de Juglandaceae provenant Cantal. - Revue générale de botanique, 81: 143-257.

Rajput, M. T. M., Khan, K. M. (1982): Two new species of fossil woods from Ranikot Fort area of Sind. - Pakistan Journal of Botany, 14: 75-87.

Ramírez, J. L., Cevallos-Ferriz, S. R. S. (2002): A diverse assemblage of Anacardiaceae from Oligocene sediment, Tepexi de Rodriguez, Puebla, Mexico. - American Journal of Botany, 89(3): 535-545. https://doi.org/10.3732/ajb.89.3.535

Retallack, G. J., Bestland, E. A., Fremd, T. J. (2000): Eocene and Oligocene paleosols of central Oregon. - Geological Society of America Special Paper, 344: 1-192. https://doi.org/10.1130/0-8137-2344-2.1

Rodríguez-Reyes, O., Falcon-Lang, H., Gasson, P., Collinson, M., Jaramillo, C. (2014): Fossil woods (Malvaceae) from the lower Miocene (early to mid-Burdigalian) part of the Cucaracha Formation of Panama (Central America) and their biogeographic implications. - Review of Palaeobotany and Palynology, 209: 11-34. https://doi.org/10.1016/j.revpalbo.2014.05.006

Sakala, J., Privé-Gill, C. (2004): Oligocene angiosperm woods from northwestern Bohemia, Czech Republic. IAWA Journal, 25(3): 369-380. https://doi.org/10.1163/22941932-90000372

Sattarian, A. (2006): Contributions to the biosystematics of Celtis L. (Celtidaceae) with special emphasis on the African species (PhD diss., Wageningen University, Wageningen, the Netherlands). - n. s., Wageningen, 142 pp. (ISBN 90-8504-445-6; copy available on-line)

Scott, R. A. (1954): Fossil fruits and seeds from the Eocene Clarno Formation of Oregon. - Palaeontographica, Abt. B, 96: 66-97, pls 15-16.

Scott, R. A., Wheeler, E. A. (1982): Fossil woods from the Eocene Clarno Formation of Oregon. - IAWA Bulletin, n. S., 3: 135-154. https://doi.org/10.1163/22941932-90000829

Selmeier, A. (1989): Ein jungtertiäres Celtis-Holz (Ulmaceae) aus der Südlichen Frankenalb (Bayern). - Archaeopteryx, 7: 35-50.

Selmeier, A. (2000a): A silicified Pistacia wood, Anacardiaceae, from the Upper Miocene of southern Franconia Alb, Germany. - Mitteilungun der Bayerischen Staatssammlung für Paläontologie und Historische Geologie, 40: 201-212. 
Selmeier, A. (2000b): Structural variation of Tertiary Grewia woods (Tiliaceae) from East Bavarian Molasse, Germany. - Feddes Repertorium, 111(7-8): 465-480. https://doi.org/10.1002/fedr.20001110713

Selmeier, A. (2015): Anatomie tertiärer Kieselhölzer aus dem nordalpinen Molassebecken / Anatomy of Tertiary silicified woods from the North Alpine Foreland Basin. Herstellung im Selbstverlag [Alfred Selmeier, Ralf Rosin], [München], $232 \mathrm{pp}$.

Selmeier, A., Velitzelos, E. (2000): Neue Aufsammlungen von verkieselten Holzresten aus tertiären Schichten Griechenlands (Lesbos, Kastoria, Thrakien). - Mitteilungun der Bayerischen Staatssammlung für Paläontologie und Historische Geologie, 40: 213-227.

Skvortsova, N. T. (1975): Sravnitel'no-morfoloicheskoe izuchenie npredstaviteley semeystva Hamamelidaceae R.Br. i ikh filogeneticheskie svyazi [Comparative morphological study of representatives of the family Hamamelidaceae R.Br. and their phylogenetic relationships]. - In: Budantsev, L. Yu. (ed.), Voprosy sravnitel'noy morfologii semennykh rasteniy [Issues of comparative morphology of seed plants]. Nauka, Leningrad, pp. 7-24. (in Russian)

Stanford, A. M., Harden, R., Clark, C. R. (2000): Phylogeny and biogeography of Juglans (Juglandaceae) based on $m a t K$ and ITS sequence data. - American Journal of Botany, 87(6): 872-882. https://doi.org/10.2307/2656895

Süss, H. (1967): Über die Längenänderungen der Parenchymstränge, Holzfasern und Gefässglieder von Laubhölzern im Verlauf einer Zuwachsperiode. - Holz als Rohund Werstoff, 25: 369-377. https://doi.org/10.1007/BF02615727

Süss, H. (1986): Untersuchungen über fossile Buchenhölzer. Beiträge zu einer Monographie der Gattung Fagoxylon Stopes \& Fujii. - Feddes Repertorium, 97(3-4): 161-183. https://doi.org/10.1002/fedr.4910970310

Süss, H., Müller-Stoll, W. R. (1977): Untersuchungen über fossile Platanenhölzer. Beiträge zu einter Monographie der Gattung Platanoxylon Andreansky. - Feddes Repertorium, 88(1-2): 1-62. https://doi.org/10.1002/fedr.19770880102

Suzuki, M., Ohba, H. (1991): A revision of fossil wood of Quercus and its allies in Japan. - Journal of Japanese Botany, 66(5): 255-274.

Sweitzer, E. M. (1971): Comparative anatomy of Ulmaceae.Journal of the Arnold Arboretum, 52: 523-585. https://doi.org/10.5962/bhl.part.9117

Takahashi, A., Suzuki, M. (1988): Two new fossil woods of Acer and a new combination of Prunus from the Tertiary of Japan. - Botanical Magazine, Tokyo, 101: 474-481. https://doi.org/10.1007/BF02488089

Takahashi, A., Suzuki, M. (2003): Dicotyledonous fossil wood flora and early evolution of wood characters in the Cretaceous of Hokkaido, Japan. - IAWA Journal, 24(3): 269-309. https://doi.org/10.1163/22941932-90001597

Tang, Y. (1943): Systematic anatomy of the woods of the Hamamelidaceae. - Bulletin of the Fan Memorial Institute of Biology, New Series, 1(1): 8-63.

Terada, K., Suzuki, M. (1998): Revision of the so-called 'Reevesia' fossil woods from the Tertiary in Japan - a proposal of the new genus Wataria (Sterculiaceae). Review of Palaeobotany and Palynology, 103: 235-251. https://doi.org/10.1016/S0034-6667(98)00039-6

Terrazas, T. T. (1994): Wood anatomy of the Anacardiaceae: Ecological and phylogenetic interpretation; Unpublished Ph.D. Dissertation. - University of North Carolina at Chapel Hill, Chapel Hill, USA, 321 pp.

Trivedi, T. K. (1971): New fossil woods of Ulmaceae and Bombacaceae from the Intertrappean beds of Mahurzari near Nagur. - In: Abstracts, Silver Jubilee Celebrations Palaeobotanical Conference (Birbal Sahni Institute of Palaeobotany), December 5-11, 1971. Lucknow, India, p. 75.

Watari, S. (1952): Dicotyledonous woods from the Miocene along the Japan-Sea of Honsyu. - Journal of the Faculty of Sciences, University of Tokyo, Sect. III, Botany, 6: 97-134.

Wheeler, E. A. (2011): InsideWood - A web resource for hardwood anatomy. - IAWA Journal, 32: 99-211. https://doi.org/10.1163/22941932-90000051

Wheeler, E. A., Baas, P., Manchester, S. R. (2022): Wood anatomy of modern and fossil Fagales in relation to phylogenetic hypotheses, familial classification, and patterns of character evolution. - International Journal of Plant Sciences, 183(1): 61-86. [published online November 12, 2021] https://doi.org/10.1086/717328

Wheeler, E. A., Dillhoff, T. A. (2009): The Middle Miocene Wood Flora of Vantage, Washington, USA. - IAWA Journal, Supplement 7: 1-101.

Wheeler, E. A., Gasson, P. E., Baas, P. (2020): Using the InsideWood web site: Potentials and pitfalls. - IAWA Journal, 41(4): 412-462. https://doi.org/10.1163/22941932-bja10032

Wheeler, E. A., LaPasha, C. A., Miller, R. B. (1988): Wood anatomy of elm (Ulmus) and hackberry (Celtis) species native to the United States. - IAWA Bulletin, n. s., 10: 5-26. https://doi.org/10.1163/22941932-90001106

Wheeler, E. A, Lee, J., Baas, P. (2010): Wood anatomy of the Altingiaceae and Hamamelidaceae. - IAWA Journal, 31(4): 399-423. https://doi.org/10.1163/22941932-90000032

Wheeler, E. A., Manchester, S. R. (2002): Woods of the Middle Eocene Nut Beds Flora, Clarno Formation, Oregon, USA. - IAWA Journal, Supplement 3: 1-188.

Wheeler, E. A., Manchester, S. R. (2007): Review of the wood anatomy of extant Ulmaceae as context for new reports of late Eocene Ulmus woods. - Bulletin of Geosciences, 82(4): 329-342. https://doi.org/10.3140/bull.geosci.2007.04.329

Wheeler, E. A., Manchester, S. R. (2014): Middle Eocene trees of central Oregon. - Paleobios, 30(3): 105-114. https://doi.org/10.5070/P9303022471

Wheeler, E. F., Scott, R. A., Barghoorn, E. S. (1978): Fossil dicotyledonous woods from Yellowstone National Park. II. - Journal of the Arnold Arboretum, 59: 1-26. https://doi.org/10.5962/p.185868

Wolfe, J. A., Tanai, T. (1987): Systematics, phylogeny, and distribution of Acer (maples) in the Cenozoic of western North America. - Journal of the Faculty of Sciences, Hokkaido University, Series IV, Geology and mineralogy, 22(1): 1-246. 
Wood Identification Database Team, FFPRI (accessed 20202021): FFPRI Wood Database. Published on the Internet. http://db.ffpri.affrc.go.jp/WoodDB/index-E.html

Wurzinger, W. (1953): Palaeobotanische Untersuchungen an tertiären Pflanzenresten aus Steiermark; Dissertation Doktorgrades [Ph.D. thesis]. - MS, Philosophischen Fakultät, Universität Wien, Wien, Austria, 190 pp.

Xie, T., Yang, Z.-Y., Wen, J., Li, D.-Z., Yi, T.-S. (2014): Biogeographic history of Pistacia (Anacardiaceae), emphasizing the evolution of the Madrean-Tethyan and the eastern Asian-Tethyan disjunctions. - Molecular Phylogenetics and Evolution, 77: 136-146.

https://doi.org/10.1016/j.ympev.2014.04.006
Yi, T., Wen, J., Golan-Goldhirsch, A., Parfitt, D. E. (2008): Phylogenetics and reticulate evolution in Pistacia (Anacardiaceae). - American Journal of Botany, 95(2): 242-251. https://doi.org/10.3732/ajb.95.2.241

Zhong, Y., Baas, P., Wheeler, E. A. (1992): Wood anatomy of trees and shrubs from China. IV. Ulmaceae. - IAWA Bulletin, n. s., 13(4): 419-453.

https://doi.org/10.1163/22941932-90001299 